\title{
Impact of the Hoa Binh dam (Vietnam) on water and sediment budgets in the Red River basin and delta
}

\author{
V. D. Vinh ${ }^{1}$, S. Ouillon ${ }^{2,3}$, T. D. Thanh ${ }^{1}$, and L. V. Chu $^{4}$ \\ ${ }^{1}$ Institute of Marine Environment and Resources, VAST, 246 Danang Street, Haiphong, Vietnam \\ ${ }^{2}$ IRD, Université de Toulouse, UPS (OMP), UMR5566 - LEGOS, 14 av. Edouard Belin, 31400 Toulouse, France \\ ${ }^{3}$ University of Science and Technology of Hanoi (USTH), 18 Hoang Quoc Viet, Cau Giay, Hanoi, Vietnam \\ ${ }^{4}$ Vietnam Institute of Meteorology, Hydrology and Environment, 62 Nguyen Chi Thanh, Hanoi, Vietnam
}

Correspondence to: S. Ouillon (sylvain.ouillon@ird.fr)

Received: 25 November 2013 - Published in Hydrol. Earth Syst. Sci. Discuss.: 10 January 2014

Revised: 10 September 2014 - Accepted: 10 September 2014 - Published: 10 October 2014

\begin{abstract}
The Hoa Binh dam (HBD), located on a tributary of the Red River in Vietnam, has a capacity of $9.45 \times 10^{9} \mathrm{~m}^{3}$ and was commissioned in December 1988. Although it is important for flood prevention, electricity production and irrigation in northern Vietnam, the Hoa Binh dam has also highly influenced the suspended sediment distribution in the lower Red River basin, in the delta and in the coastal zone. Its impact was analysed from a 50-year data set of water discharge and suspended sediment concentration (1960-2010), and the distribution of water and sediment across the nine mouths of the delta was simulated using the MIKE11 numerical model before and after the dam settlement. Although water discharge at the delta inlet decreased by only $9 \%$, the yearly suspended sediment flux dropped, on average, by $61 \%$ at Son Tay near Hanoi (from 119 to $46 \times 10^{6} \mathrm{tyr}^{-1}$ ). Along the coast, reduced sedimentation rates are coincident with the lower sediment delivery observed since the impoundment of the Hoa Binh dam. Water regulation has led to decreased water discharge in the wet season $(-14 \%$ in the Red River at Son Tay) and increased water discharge in the dry season $(+12 \%$ at the same station). The ratios of water and suspended sediment flows, as compared to the total flows in the nine mouths, increased in the northern and southern estuaries and decreased in the central, main Ba Lat mouth. The increasing volume of dredged sediments in the Haiphong harbour is evidence of the silting up of the northern estuary of Cam-Bach Dang. The effect of tidal pumping on enhanced flow occurring in the dry season and resulting from
\end{abstract}

changed water regulation is discussed as a possible cause of the enhanced siltation of the estuary after Hoa Binh dam impoundment.

\section{Introduction}

Asia and Oceania contribute $70 \%$ of the global sediment supply from land to the ocean (Milliman and Syvitski, 1992; Farnsworth and Milliman, 2003). However, recent human activities on large rivers have severely altered sediment discharge, mainly as a consequence of artificial impoundments (Syvitski et al., 2005). Vörösmarty et al. (2003) estimated that around $53 \%$ of sediment flux is now potentially trapped in reservoirs. This reduction in sediment flux dramatically affects deltas (Ouillon, 1998; Syvitski and Saito, 2007). For example, sediment discharge decreased from 480 to approximately $150 \times 10^{6} \mathrm{t} \mathrm{yr}^{-1}$ over a 20 -year period in the Yangtze River (Changjiang) (Yang et al., 2006; Wang et al., 2008) and from 1080 to $150 \times 10^{6} \mathrm{tyr}^{-1}$ over a 40 -year period in the Yellow River (Huanghe) (Wang et al., 2007). Large rivers and their deltas in Southeast Asia have also been impacted by other human activities such as groundwater pumping, irrigation, dredging and deforestation (Tran et al., 2004; Saito et al., 2007).

The Red River delta (RRD), located on the western coast of the Gulf of Tonkin, is the fourth largest delta in Southeast Asia in terms of delta plain surface, after the Mekong, 


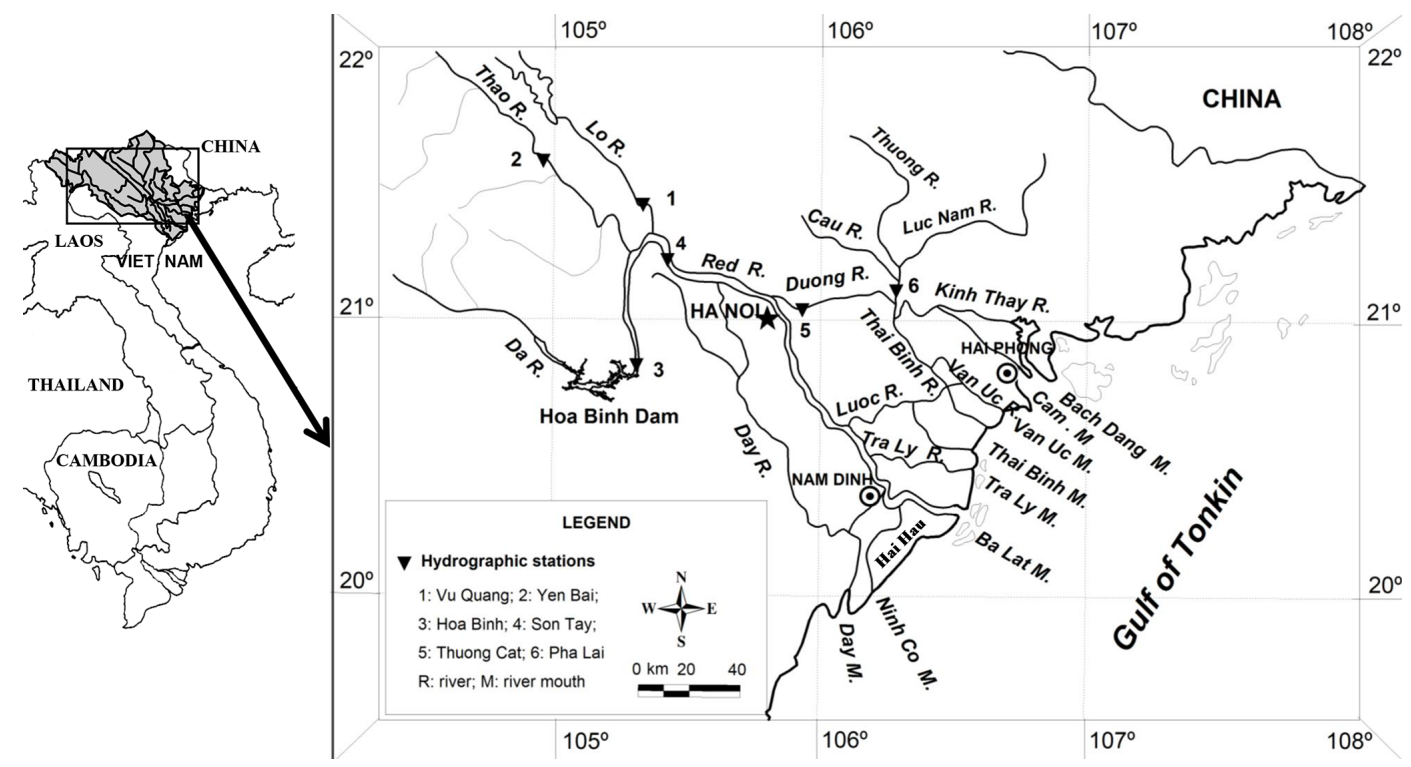

Figure 1. Red River system and the Red River coastal area.

Irrawaddy, and Chao Phraya deltas. The RRD formed in the vicinity of Hanoi about 8000-9000 years ago. It then prograded with a triangular morphology with an apex near Son Tay, and expanded to reach its current area of $14300 \mathrm{~km}^{2}$ (Tanabe et al., 2003, 2005; Hori et al., 2004; Luu et al., 2010) (Fig. 1). The RRD lies entirely below $6 \mathrm{~m}$ a.s.l. (above sea level). Its population was estimated as 16.6 million in 2006, corresponding to an average population density of 1160 inhabitants $\mathrm{km}^{-2}$ (Luu et al., 2010).

The Red River (Song Hong) drains a basin area of $160 \times 10^{3} \mathrm{~km}^{2}$ (Milliman et al., 1995). Its average discharge over 1902-1990 at Son Tay was $3740 \mathrm{~m}^{3} \mathrm{~s}^{-1}$ (To, 2000, quoted by Le et al., 2007). The Red River has two main tributaries, the Lo (or Clear) River and the Da (or Black) River. The last four major floods of the Red River within the return period of 100 years were caused by simultaneous high floods in the Lo, Da and Thao rivers. The Da River usually played the main role, representing $53-57 \%$ of the total discharge (Le et al., 2007). During the biggest flood ever recorded, the water level in Hanoi reached $13.3 \mathrm{~m}$ in August 1971 (Luu et al., 2010), and the Ba Lat River mouth shifted $10 \mathrm{~km}$ southwards to its current position (van Maren, 2004, 2007).

The construction of the Hoa Binh dam (HBD) on the Da River began on 6 November 1979 and ended on 30 December 1988. The HBD has a capacity of $9.45 \times 10^{9} \mathrm{~m}^{3}$ of water, corresponding to $18 \%$ of the annual discharge of the Da River, and has an electric power plant of $1920 \mathrm{MW}$ delivering about $40 \%$ of Vietnamese electricity production (Le et al., 2007). In 2012, it was ranked 53rd in the world in terms of electric capacity (International Commission on Large Dams, ICOLD, http://www.icold-cigb.org/). Since its impoundment, the HBD has played an important role in flood prevention, electricity production and irrigation supply in northern Vietnam.

Before HBD impoundment, the Red River suspended sediment flux was estimated to be $100-160 \times 10^{6} \mathrm{tyr}^{-1}$ at Son Tay (Milliman et al., 1995; Pruszak et al., 2002), corresponding to a specific sediment delivery of 700 to $1100 \mathrm{t} \mathrm{km}^{-2} \mathrm{yr}^{-1}$, as compared to a global average of $120 \mathrm{t} \mathrm{km}^{-2} \mathrm{yr}^{-1}$ (Achite and Ouillon, 2007). At $160 \times 10^{6} \mathrm{tyr}^{-1}$, the Red River was ranked as the ninth river in terms of sediment flux by Milliman and Meade (1983). The Da River was its main sediment provider until the building of the HBD in the 1980s (Dang et al., 2010). Recent studies have shown that the sediment flux drastically decreased to around $40 \times 10^{6} \mathrm{t} \mathrm{yr}^{-1}$ during the 1997-2004 period following HBD impoundment (Le et al., 2007). The mean annual sediment trapping efficiency of the Hoa Binh reservoir was estimated to be $88 \%$, suggesting that the HBD reduces annual sediment delivery to the delta by half (Dang et al., 2010).

The Red River water and sediment discharges are distributed amongst a complex network of connected distributaries with nine river mouths (Fig. 1). Despite the decrease in sediment discharge, Haiphong harbour, located in the Cam estuary, one of the northern distributaries, is silting up (Lefebvre et al., 2012). This silting up has huge economic consequences, rendering urgent the need for an analysis of suspended sediment flux changes in the river basin. In the coastal zone, van Maren (2004) showed that the decrease in suspended sediment downstream of the HBD affects sediment fluxes in the Ba Lat area. After the dam impoundment, the alongshore sediment transport rate in shallow water increased from $200000 \mathrm{~m}^{3} \mathrm{yr}^{-1}$ in 1949 to $300000 \mathrm{~m}^{3} \mathrm{yr}^{-1}$ in 2000 , while in deeper waters $(10-30 \mathrm{~m})$ in the Ba Lat coastal 
area, it decreased from a peak of $500000 \mathrm{~m}^{3} \mathrm{yr}^{-1}$ in 1949 to $300000 \mathrm{~m}^{3} \mathrm{yr}^{-1}$ in 2000. Although Luu et al. (2010) estimated the water discharge distribution in the northern, central and southern part of the delta after HBD commissioning, the water and suspended sediment distribution of the Red River across its nine mouths has yet to be documented.

This paper aims at complementing the previous studies both in the Red River basin and in its delta before and after HBD impoundment. Water and sediment fluxes from the three main tributaries were averaged over a long-term series of measurements before and after HBD impoundment (for 20 years before, 1960-1979, and 22 years after, 19892010). The variability of water and sediment discharge is examined at different timescales (seasonal, inter-annual) from measurements, and the impact of the HBD is assessed. Discharge and sediment concentration have been continuously measured upstream, but no systematic record exists in the Red River delta, where only water level is available at the hydrological stations. This paper provides a first estimate of the water and sediment discharge distribution amongst the nine distributaries, for before and after the HBD, from numerical simulations. New data on recent changes in sediment deposition and erosion in estuaries and along the delta coastline are also given and discussed considering the new water regulation.

\section{Regional settings}

\subsection{Geography}

The Red River source is located at a mean elevation of $2000 \mathrm{~m}$ in the mountains of the Yunnan province in China (Nguyen and Nguyen, 2001). It is called the Yuan River in China, and flows into Vietnam, where it is named the Hong or Thao River because of its reddish-brown water, due to its huge sediment delivery and to the richness of sediments in iron dioxide. The Red River receives two major tributaries: the Da River and the Lo River (Fig. 1). Their drainage basins are $57.2 \times 10^{3} \mathrm{~km}^{2}$ for the Thao River (of which $21 \%$ is in Vietnam), $51.3 \times 10^{3} \mathrm{~km}^{2}$ (52\% in Vietnam) for the $\mathrm{Da}$, and $34.6 \times 10^{3} \mathrm{~km}^{2}$ (64\% in Vietnam) for the Lo. The Da River also originates in the Yunnan province, the elevation of its source being at $2000 \mathrm{~m}$. The source of the Lo River is located in China at an elevation of $1100 \mathrm{~m}$, and joins the main branch at Viet Tri (Nguyen and Nguyen, 2001). The Red River flows $1200 \mathrm{~km}$ before it empties into the Gulf of Tonkin (Bac Bo, in Vietnamese) in the East Sea of Vietnam (South China Sea).

After the confluence of the Da, Thao, and Lo rivers, the Red River gradient falls to $5.9 \times 10^{-5}$ downstream of the apex of the delta (Gourou, 1936, quoted by van Maren, 2007), and the river diverges into two major distributaries a few kilometres upstream of Hanoi: the Red River to the southwest and the Thai Binh River to the northeast (Fig. 1). In the southwest, the Red River system includes the Tra Ly
River, the Red River, the Ninh Co River and the Day River. On the left bank of the Red River, the Duong River is a main distributary (Fig. 2). At Pha Lai in the delta, the DuongThai Binh system receives water and sediment from the Cau River (288 km long), the Thuong River (157 km long) and the Luc Nam River (200 km long), and supplies water and sediment to the northeastern parts of the Red River delta. Finally, the Red-Thai Binh river system has, from northeast to southwest, the Cam-Bach Dang mouth (the Bach Dang combines with the Cam to form the Nam Trieu mouth), the Lach Tray mouth, the Van Uc mouth, the Thai Binh mouth, the Tra Ly mouth, the Ba Lat mouth, the Ninh Co (or Lach Giang) mouth, and the Day mouth (Figs. 1 and 2). The Ba Lat mouth is the main mouth of the Red River.

\subsection{Climate and rainfall}

The Red River basin is subject to a sub-tropical climate that is characterised by a summer monsoon from the south and a winter monsoon from the northeast. The wet season (from May to October) alternates with a dry season, and accounts for $85-95 \%$ of the total yearly rainfall. In the period 19972004, the mean annual rainfall was $1590 \mathrm{~mm}$ in the whole basin (Le et al., 2007). It is slightly higher on the delta, with an average value estimated to be $1667 \mathrm{~mm}$ between 1996 and 2006 by Luu et al. (2010), who give the extreme values obtained during 10 years: $1345 \mathrm{~mm} \mathrm{yr}^{-1}$ with a monthly peak of $450 \mathrm{~mm} \mathrm{month}^{-1}$ in 2006, and $1725 \mathrm{~mm} \mathrm{yr}^{-1}$ with a monthly peak of $360 \mathrm{~mm} \mathrm{month}^{-1}$ in 1996 . The mean annual potential evapotranspiration from 1997 to 2004 was rather homogeneously distributed over the whole basin area, from 880 to $1150 \mathrm{~mm} \mathrm{yr}^{-1}$ (Le et al., 2007). Episodically, typhoons hit the northern coastline of Vietnam principally from July to November. They move in a northwesterly direction and strike obliquely across the coastline (Mathers and Zalasiewicz, 1999).

\subsection{Hydrological regimes and sediment transport}

The total water and suspended sediment discharges of the Song Hong at Son Tay gauging station before HBD impoundment were $120 \mathrm{~km}^{3} \mathrm{yr}^{-1}$ and about $120 \times 10^{6} \mathrm{tyr}^{-1}$, respectively, and the average sediment concentration in the river was about $1 \mathrm{gL}^{-1}$, with a maximum estimated at $12 \mathrm{~g} \mathrm{~L}^{-1}$ during the highest flood ever recorded in 1971. The discharge at the Hanoi station reached a maximum in JulyAugust (about $23000 \mathrm{~m}^{3} \mathrm{~s}^{-1}$ ) and a minimum during the dry season (January-May; typically $700 \mathrm{~m}^{3} \mathrm{~s}^{-1}$ ). Approximately $90 \%$ of the annual sediment discharge was issued during the wet season (Mathers et al., 1996; Mathers and Zalasiewicz, 1999). The Duong-Thai Binh River carries approximately $20 \%$ of the total water discharge (General Department of Land Administration, 1996). The annual discharge of the Cau River is $1.6 \mathrm{~km}^{3} \mathrm{yr}^{-1}$, or $51.2 \mathrm{~m}^{3} \mathrm{~s}^{-1}$, at the Thac Buoi station, with an average suspended sediment 


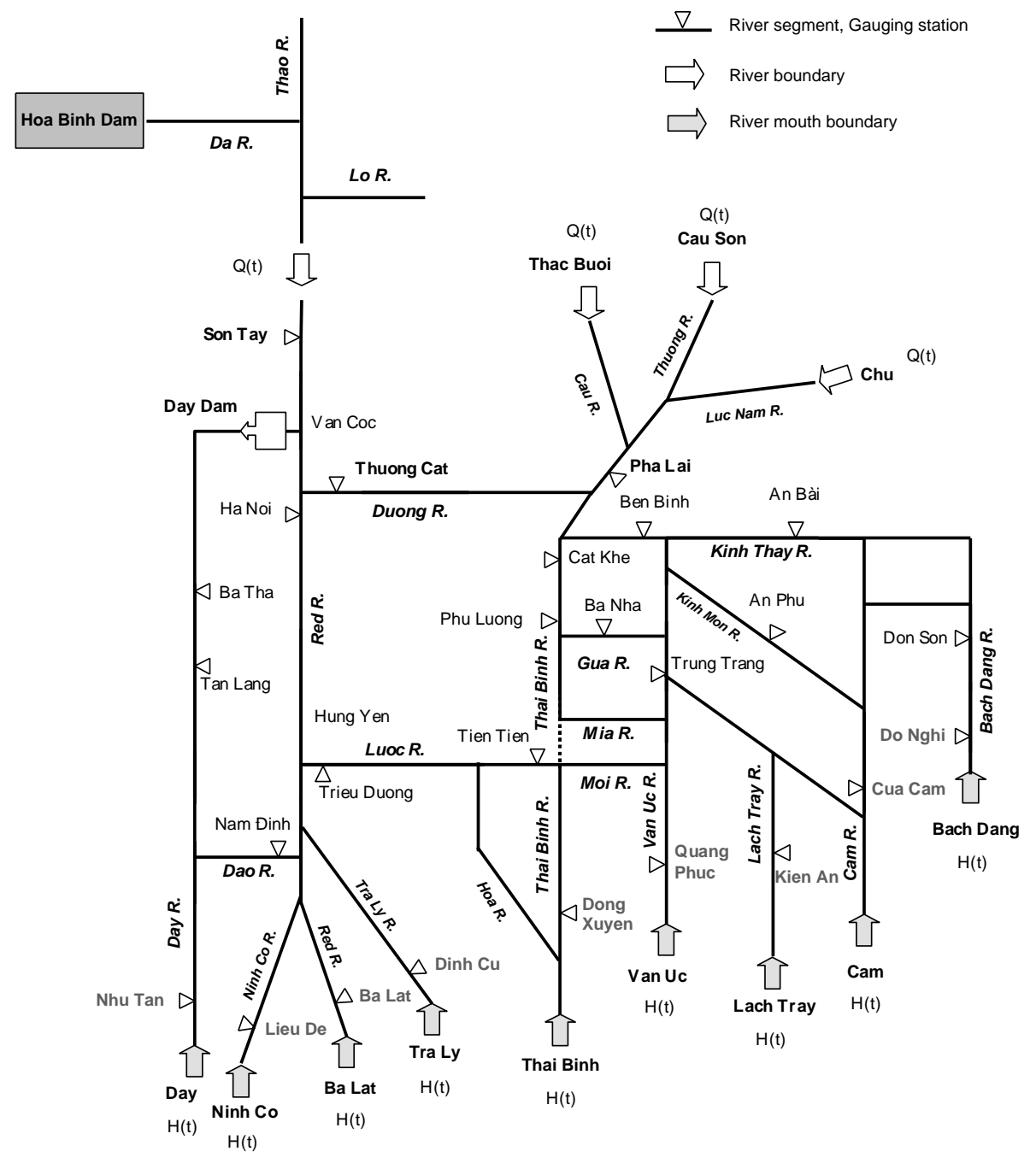

Gulf of Tonkin

Figure 2. Diagram of the network considered in the Red River delta for the MIKE11 model.

concentration of $250 \mathrm{mg} \mathrm{L}^{-1}$. Its average annual sediment discharge is $0.22 \times 10^{6} \mathrm{tyr}^{-1}$ (Nguyen, 1984; Nguyen et al., 2003). The annual discharge of the Thuong River is $1.2 \mathrm{~km}^{3} \mathrm{yr}^{-1}$ (or $40 \mathrm{~m}^{3} \mathrm{~s}^{-1}$ ) at the Cau Son station, with an average suspended sediment concentration of $122 \mathrm{mg} \mathrm{L}^{-1}$. Its annual sediment discharge is on average $0.12 \times 10^{6} \mathrm{t} \mathrm{yr}^{-1}$ (Nguyen, 1984; Nguyen et al., 2003). The annual discharge of the Luc Nam River is $1.3 \mathrm{~km}^{3} \mathrm{yr}^{-1}$ (or $42.3 \mathrm{~m}^{3} \mathrm{~s}^{-1}$ ) at the Chu station, with an average suspended sediment concentration of $330 \mathrm{mg} \mathrm{L}^{-1}$. Its annual sediment discharge averaged $0.2 \times 10^{6} \mathrm{t} \mathrm{yr}^{-1}$ (Nguyen, 1984; Nguyen et al., 2003). These rivers experience a flood season from June to October which brings 70-81\% of their total annual water input and 85-92\% of their total sediment input to the Thai Binh River system.

\subsection{Tide and tidal influence in the estuaries}

The tide in the Gulf of Tonkin is predominantly diurnal, with one ebb-flood cycle occurring each day, and an amplitude gradually decreasing from 4 to $2 \mathrm{~m}$ from north to south during spring tides (Fang et al., 1999; Nguyen et al., 2014) (see Fig. 1). Within the spring-neap 14-day cycle, the tide amplitude at $\mathrm{Ba}$ Lat varies from $2.5 \mathrm{~m}$ during spring tides to $0.5 \mathrm{~m}$ during neap tides.

Salinity intrusion occurs for up to $40 \mathrm{~km}$ landwards from the Cam River mouth within the delta, $38 \mathrm{~km}$ from the Lach Tray mouth, $28 \mathrm{~km}$ from the Thai Binh mouth and $20 \mathrm{~km}$ from the Ba Lat mouth (Fig. 1). However, the tidal influence on water level and discharge extends much farther upstream. At Phu Ly (120 km from the coast) on the Day River, daily water levels induced by the tidal propagation vary by $1 \mathrm{~m}$ 
during the dry season and by $0.6 \mathrm{~m}$ during the wet season (Luu et al., 2010).

Tidal mechanisms are key processes in water distribution in deltas, since they may alter the discharge division amongst distributaries by several percentage values (from $10 \%$ at the apex to $30 \%$ seaward in the Mahakam delta, Indonesia; Sassi et al., 2011). Tidal mechanisms are also key processes in sediment transport in estuaries (e.g. Allen et al., 1980; Dyer, 1986; Dronkers, 1986; Sassi et al., 2013). In the middle and lower estuaries, deposition is mainly driven by the dynamics of the turbidity maximum zone, whose presence and dynamics are governed by the coupling between river discharge and tidal propagation (e.g. tidal pumping and/or density gradients; Sottolochio et al., 2001). Tidal pumping is caused by the asymmetry of tides, with shorter and more energetic flood periods than ebb periods, and longer high slack water periods than low slack waters, thus favouring deposition near the turbidity maximum (Allen et al., 1980; Uncles et al., 1985; Dyer, 1986; Dronkers, 1986). Fluid mud consolidates slightly during neap tides (Dyer, 1986).

Lefebvre et al. (2012) showed that suspended sediment deposition induced by tidal pumping in the Cam-Bach Dang estuary (Fig. 1) can be up to three times higher during the dry season relative to the wet season. During the dry season, the net sediment flux at the river mouth is positive from the sea to the Cam-Bach Dang estuary, bringing back into the estuary particles brought by previous floods (Lefebvre et al., 2012).

In this study, tidal propagation within the estuaries is included in the numerical model, and the tide is taken into account through its boundary conditions in the river mouths.

\subsection{Fluvial, tidal and wave influences along the delta coastline}

Fluvial-, tide- and wave-dominated processes appear to be important in the development of the RRD, but their relative influence is subject to a remarkable spatial variability (Mathers and Zalasiewicz, 1999; van Maren, 2004, 2007). The northern coastal section of the RRD lies sheltered from strong wave action by the island of Hainan, and the river mouths are mostly funnel shaped as a consequence of the prevalence of river and tidal forces. In the southern part of the delta, the river mouths are mainly convex in shape as a consequence of the dominant wave forces (Pruszak et al., 2005). The central part of the delta, around the Ba Lat mouth, is a mixed tide- and wave-dominated coast. The estuaries are mainly composed of silts, and sand is estimated to be, on average, $10 \%$ of the surface sediments in the mouths of the Red River (Tran and Tran, 1995).

\subsection{Grain size within the river basin and the delta}

Values of the median diameter $D_{50}$ of surface sediment are, on average, $0.35,0.16$ and $0.175 \mathrm{~mm}$ in the $\mathrm{Da}$, Thao and Lo rivers, respectively (Ministry of Agriculture and Rural Development, 2009). Its value is $0.2 \mathrm{~mm}$ between the confluence of the Da and Thao rivers and the apex and, in the upper two distributaries, $0.18 \mathrm{~mm}$ in the Red River and $0.22 \mathrm{~mm}$ in the Duong River (Ministry of Agriculture and Rural Development, 2009). Downstream, in the estuaries and coastal zones, $D_{50}$ of the superficial sediments ranges from 5 to $195 \mu \mathrm{m}$ (Do et al., 2007). In the lower Cam-Bach Dang estuary, surface sediments result from a combination of fine silt and fine sand whose ratio varies greatly over a distance of $5-10 \mathrm{~km}$ (Lefebvre et al., 2012).

\section{Data and methods}

\subsection{Data}

The data used in this paper are daily water discharge $(Q)$ and suspended sediment concentration $(C)$ over the 50-year period from 1960-2010 (MONRE, 1960-2010). This time period covers the time before (1960-1979) and after (19892010) HBD impoundment. The data were collected by the National Hydro-Meteorological Service (NHMS) at the hydrographic stations of the Red River system (Fig. 1): Vu Quang (Lo River), Yen Bai (Thao River), Hoa Binh (Da River), Son Tay (Red River), Hanoi (Red River) and Thuong Cat (Duong River). Calculations were carried out according to the TCN26-2002 norm of the Vietnamese Hydrometeorology General Department. Measurements were conducted following the standards of the IMHEN (Institute of Meteorology, Hydrology and Environment) belonging to the Ministry of Natural Resources and Environment (MONRE), which apply all over Vietnam to each gauging station, with the same protocols. NHMS provided daily discharge from water depth, which was measured every minute. Regular calibrations of the water depth-discharge rating curve were conducted (several times a month) at key stations of the Red River, using reels (every $20 \mathrm{~m}$ across the river section, at five depths over the water column) and, more recently, acoustic Doppler current profilers (ADCPs). Water was sampled along a water column representative of the cross section to determine $C$ after filtration on pre-weighted filters of $0.45 \mu \mathrm{m}$ porosity: once a day at 07:00 LT (local time) during low discharge, and twice a day or more during floods. Detailed cross sections of velocity and $C$ were gauged once a day during high floods. The data were quality controlled by the HydroMeteorological Data Center (HDC).

Independent validations of discharge estimates (by ADCP) and $C$ estimates (by filtration techniques) were conducted by Dang et al. in 2008 (Dang et al., 2010; Dang, 2011) on the Red River at Son Tay. Their study shows (1) that daily $C$ concentrations and the $Q$ provided by MONRE can be considered accurate, within 10-15\%, and (2) that the scatter error was probably random rather than systematically biased (see e.g. Fig. 47 of Dang, 2011). Consequently, and considering 
the method proposed by Meade and Moody (2010) on the Mississipi River, the annual suspended sediment flux estimates on the Red River may be considered accurate within 5$10 \%$ (Dang et al., 2010). As stated by Whitemanẽt al. (2011), a high frequency of measurement is more important than a decrease in random error in trend detection, as the integration of daily data (which are already values averaged from several measurements over the day during floods) over seasons or years largely smoothed out random variation. In the present paper, considering this uncertainty, the precision given on river discharge and suspended sediment flux is limited to $1 \times 10^{9} \mathrm{~m}^{3} \mathrm{yr}^{-1}$ and $1 \times 10^{6} \mathrm{tyr}^{-1}$, respectively, for the Red River, and to $0.1 \times 10^{9} \mathrm{~m}^{3} \mathrm{yr}^{-1}$ and $0.1 \times 10^{6} \mathrm{tyr}^{-1}$ for its tributaries and distributaries.

Other data are also used in the present study:

- hourly water elevation at the nine river mouths in 1979 and 2006 measured by the NHMS;

- river sections (bed elevation across the river) measured in the Red River system by the NHMS;

- data on coastal erosion along the RRD from Tran et al. (2001, 2002, 2008);

- volumes of dredged sediments in Haiphong harbour provided by the harbour authorities.

\subsection{Calculation of water and sediment discharge in upstream rivers}

The annual water $Q_{y, i}$ (in $\mathrm{m}^{3} \mathrm{yr}^{-1}$ ) and suspended sediment discharge $M_{y, i}$ (in tyr ${ }^{-1}$ ) for year $i$ were calculated following norm TCN26-2002, as

$Q_{y, i}=\sum_{j=1}^{p} Q_{\mathrm{d}, i, j} \times 86400$

$M_{y, i}=\sum_{j=1}^{p} Q_{\mathrm{d}, i, j} \times C_{\mathrm{d}, i, j} \times 0.0864$

where $Q_{\mathrm{d}, i, j}$ (in $\mathrm{m}^{3} \mathrm{~s}^{-1}$ ) is the average water discharge at day $j$ and year $i, C_{\mathrm{d}, i, j}$ (in $\mathrm{mg} \mathrm{L}^{-1}$ ) is the suspended sediment concentration at day $j$ and year $i$, and $p$ is the number of days per year $i$.

For a given distributary $k$ amongst the nine distributaries of the Red River, the ratio of its water discharge to the Gulf of Tonkin (denoted as the $Q$ ratio) was calculated as

$$
Q \text { ratio }_{k}=\frac{Q_{k}}{\sum_{l=1}^{9} Q_{l}} .
$$

In the same way, the ratio of suspended sediment delivery to the Gulf of Tonkin (denoted as the $M$ ratio) for a given distributary $k$ amongst the nine distributaries of the Red River was calculated as
$M$ ratio $_{k}=\frac{M_{k}}{\sum_{l=1}^{9} M_{l}}$.

The $Q$ ratio and the $M$ ratio can be calculated for a given year or from the average of yearly values over a given period.

\subsection{Calculation of water and sediment discharge in estuaries}

\subsubsection{The MIKE11 model}

In order to estimate water and sediment discharge from estuaries into the coastal zone before and after HBD impoundment, a data-driven modelling approach was set up using the MIKE11 model (Vu et al., 2011). MIKE11 is a modelling package for the simulation of surface runoff, flow, sediment transport, and water quality in rivers, channels, estuaries, and floodplains (DHI, 2009). MIKE11 is an implicit finite difference model for one-dimensional unsteady flow computation, and can be applied to looped networks and quasi twodimensional flow simulations on floodplains. The model has been designed to perform detailed modelling of rivers, including special treatment of floodplains, road overtopping, culverts, gate openings and weirs. MIKE11 is capable of using kinematic, diffusive or fully dynamic, vertically integrated mass and momentum equations. The solution of continuity and momentum equations is based on an implicit finite difference scheme. This scheme is structured so as to be independent of the wave description specified. Boundary types include water level $(h)$, discharge $(Q)$, the $Q / h$ relation, wind field, dam break, and resistance factors. The water level boundary must be applied to either the upstream or downstream boundary conditions in the model, depending on the hydrodynamic regime (characterised by the Froude number). The discharge boundary can be applied to either the upstream or downstream boundary conditions, and can also be applied to the side tributary flow (lateral inflow). The lateral inflow is used to depict runoff. The $Q / h$ relation can only be applied to the downstream boundary.

\subsubsection{The cohesive sediment transport module}

The cohesive sediment transport module of MIKE11 is based on the one-dimensional advection-dispersion equation:

$$
\frac{\partial A C}{\partial t}+\frac{\partial Q C}{\partial x}-\frac{\partial}{\partial x}\left(A K_{\mathrm{H}} \frac{\partial C}{\partial x}\right)=C_{2} q+w S_{\mathrm{E}}-w S_{\mathrm{D}},
$$

where $C$ is the suspended sediment concentration $\left(\mathrm{kg} \mathrm{m}^{-3}\right)$, $A$ the cross-sectional area $\left(\mathrm{m}^{2}\right), K_{\mathrm{H}}$ the horizontal dispersion coefficient $\left(\mathrm{m}^{2} \mathrm{~s}^{-1}\right), C_{2}$ the tributary concentration, $q$ the tributary (lateral) inflow per unit length, $S_{\mathrm{E}}$ the source term resulting from erosion $\left(\mathrm{kg} \mathrm{m}^{-3} \mathrm{~s}^{-1}\right), S_{\mathrm{D}}$ the sink term resulting from deposition $\left(\mathrm{kg} \mathrm{m}^{-3} \mathrm{~s}^{-1}\right)$, and $w$ the river bed surface 
per unit length (in $\mathrm{m}^{2}$, its value being the river width $\times 1$ ). The deposition rate is given by

$$
\begin{gathered}
S_{\mathrm{D}}=\frac{W_{\mathrm{s}} C}{h_{*}}\left(1-\frac{\tau_{\mathrm{b}}}{\tau_{\mathrm{c}, \mathrm{d}}}\right) \text { for } \tau_{\mathrm{b}} \leq \tau_{\mathrm{c}, \mathrm{d}} \\
\text { and } S_{\mathrm{D}}=0 \text { for } \tau_{\mathrm{b}}>\tau_{\mathrm{c}, \mathrm{d}},
\end{gathered}
$$

where $W_{\mathrm{s}}$ is the settling velocity $\left(\mathrm{m} \mathrm{s}^{-1}\right), \tau_{\mathrm{b}}$ is the bed shear stress $\left(\mathrm{N} \mathrm{m}^{-2}\right), \tau_{\mathrm{c}, \mathrm{d}}$ is the critical bed shear stress for deposition $\left(\mathrm{N} \mathrm{m}^{-2}\right)$, and $h_{*}$ is the average depth through which the particles settle $(\mathrm{m})$, calculated by the model from the water depth and the Rouse number (see DHI, 2009). The rate of erosion is given by

$$
\begin{aligned}
S_{\mathrm{E}}= & \frac{M_{*}}{h}\left(\frac{\tau_{\mathrm{b}}}{\tau_{\mathrm{c}, \mathrm{e}}}-1\right) \text { for } \tau_{\mathrm{b}} \geq \tau_{\mathrm{c}, \mathrm{e}} \\
& \text { and } S_{\mathrm{E}}=0 \text { for } \tau_{\mathrm{b}}<\tau_{\mathrm{c}, \mathrm{e}}
\end{aligned}
$$

where $M_{*}$ is the erodibility of the bed $\left(\mathrm{kg} \mathrm{m}^{-2} \mathrm{~s}^{-1}\right), \tau_{\mathrm{c}, \mathrm{e}}$ the critical shear stress for erosion $\left(\mathrm{N} \mathrm{m}^{-2}\right)$, and $h$ is the water depth. In our simulations, sediment was always assumed to be available at the bed for erosion.

The resolution of the cohesive sediment transport module requires outputs from the hydrodynamics module, namely water discharge, water level, cross-sectional area and hydraulic radius, and calibrated specific parameters (critical shear stress for erosion, critical shear stress for deposition, erodibility). This cohesive sediment transport module associated with MIKE11 has been successfully applied to sediment transport studies by, e.g., Neary et al. (2001), EtemadShahidi et al. (2010) and Kourgialas and Karatzas (2014).

\subsubsection{Application to the Red River delta}

In order to set up the model, the Red River system was designed under a network which includes the main rivers (Fig. 2) from data such as river section and bed elevation collected by the NHMS. To implement our model, 783 river sections provided by MONRE were used: 51 sections of the Da River, 27 of the Thao River, 19 of the Lo River, 156 of the Red River, 44 of the Thai Binh River, 34 of the Luoc River, 31 of the Duong River, and 421 of other rivers or channels of the network (Fig. 2).

For calibration and validation purposes, the model was run with actual data, for real situations. In every calculation, the model ran for 32 days for the spin-up before the true simulation began. To study the impact of the HBD, the model was run for two typical years as defined by the average of daily $Q$ and $C$ data before (1960-1979) and after (19892010) HBD impoundment. The hourly boundary conditions in water elevation at the river mouths came from measurements performed at the gauging stations in 1979 and 2006, respectively.

\subsubsection{Boundary conditions}

Upper boundaries were fixed across sections at Son Tay on the Red River, and at Thac Buoi (Cau River), Cau Son (Thuong River) and Chu (Luc Nam River). Daily $Q$ and $C$ were used as inputs at these cross sections. Hourly water levels were imposed as boundary conditions in the Bach Dang, Cam, Lach Tray, Van Uc, Thai Binh, Tra Ly, Ba Lat, Ninh Co and Day river mouths. While $C$ at these estuarine boundaries was calculated by the model during ebb periods, we chose to fix it during the flood period. A varying $C$ at river mouths during floods would necessitate either available continuous measurements, or a coupling to a coastal sediment transport model, out of the scope of the present study.

The value of $C$ at the ocean boundaries during flood was obtained from the available measurements. Continuous measurements of periods longer than the spring-neap tide cycle were performed on the Cam and Van Uc rivers in March (dry season) and August (wet season) 2009 at the Cam River mouth and at the Van Uc River mouth. The averaged $C$ at the Cam mouth during flood tide was $52 \mathrm{mg} \mathrm{L}^{-1}$ in the dry season and $61 \mathrm{mg} \mathrm{L}^{-1}$ in the wet season, while it was $60 \mathrm{mg} \mathrm{L}^{-1}$ in the dry season and $95 \mathrm{mg} \mathrm{L}^{-1}$ in the wet season in the Van Uc River. Other series of measurements were performed during one tidal cycle at the Cam, Bach Dang and Dinh Vu river mouths (Dinh Vu is located just downstream of the confluence between Cam and Bach Dang) in the wet season in 2008, and in the dry season in 2009 (field campaigns presented in Rochelle-Newall et al., 2011; Lefebvre et al., 2012; Mari et al., 2012). During flood tides, at $1.5 \mathrm{~m}$ below the surface, the averaged values lay in the range $72-162 \mathrm{mg} \mathrm{L}^{-1}$ in the wet season and $28-72 \mathrm{mg} \mathrm{L}^{-1}$ in the dry season. $C$ values were always higher at the beginning of flood (just after low tide) than at the end, just before high tide.

As no measurements were available for the other river mouths, we decided to fix in our calculations a constant value of $50 \mathrm{mg} \mathrm{L}^{-1}$ at each river mouth over the whole year during flood periods. This value is within the range and the order of magnitude for the Cam, Bach Dang and Van Uc rivers.

\subsubsection{Calibration and validation}

The model was calibrated by changing the values of Manning's roughness coefficients $(n)$ at different locations in the river reach. During calibration, the simulated and observed water discharges at the Hanoi, Thuong Cat, Nam Dinh, and Cua Cam gauging sites were compared for different combinations of $n$ until the simulated and observed water levels matched closely. Optimisation of the model's parameters $(n$ distribution for hydrodynamics, critical shear stress for erosion $\tau_{\mathrm{c}, \mathrm{e}}$, critical shear stress for deposition $\tau_{\mathrm{c}, \mathrm{d}}$ and erodibility $M_{*}$ for suspended sediment transport) was based on the Nash-Sutcliffe efficiency coefficient $E$ (Nash and Sutcliffe, 1970) calculated for each simulation and given by 


$$
E=1-\frac{\sum(\operatorname{obs} Q-\operatorname{calc} Q)^{2}}{\sum(\operatorname{obs} Q-\operatorname{mean} Q)^{2}},
$$

in which the sum of the absolute squared differences between the predicted and observed values $(Q$ for hydrodynamics, $C$ for sediment transport) is normalised by the variance of the observed values during the period under investigation. $E$ varies from 1.0 (perfect fit) to $-\infty$, a negative value indicating that the mean value of the observed time series would have been a better predictor than the model (Krause et al., 2005).

The values of $n$ used during the calibration process were within the range of $0.020-0.035 \mathrm{~m}^{-1 / 3} \mathrm{~s}$ as recommended by Chow (1959). To avoid model instability, appropriate computational time steps and grid sizes were selected. In the model set-up, the computational time step and grid size were assigned as $30 \mathrm{~s}$ and $1000 \mathrm{~m}$, respectively. Initial water level and discharge conditions were provided to avoid a dry bed situation. Initially, the model was run using a uniform roughness coefficient of $0.03 \mathrm{~m}^{-1 / 3} \mathrm{~s}$. During the initial runs, the model over-estimated the water level at some stations. Local values of Manning's $n$ were chosen at different locations along the river to obtain the best fit between measurements and simulations. The resulting calibration was obtained with a decreasing roughness coefficient from $0.035 \mathrm{~m}^{-1 / 3} \mathrm{~s}$ (upstream) down to $0.02 \mathrm{~m}^{-1 / 3} \mathrm{~s}$ (downstream), by a local best fit at the gauging stations. No assumption about the type of global decrease from upstream to downstream (either linear, exponential or other) was made, but a linear variation was applied to determine the $n$ between two adjacent gauging stations.

Only one class of particles, of $15 \mu \mathrm{m}$ in diameter, was considered in our simulations. This value is in agreement with bed sediment sizes in the estuaries, dominated by silts (see Sect. 2.6 and Lefebvre et al., 2012). Their corresponding settling velocity obtained from Stoke's law is $0.2 \mathrm{~mm} \mathrm{~s}^{-1}$. The critical shear stress for erosion of sediment $\left(\tau_{\mathrm{c}, \mathrm{e}}\right)$ was tested in the range $0.1-1.0 \mathrm{~N} \mathrm{~m}^{-2}$ (Van Rijn, 2005); after calibration, we selected a value of $0.2 \mathrm{~N} \mathrm{~m}^{-2}$ for our simulations. The critical shear stress for deposition of sediment $\left(\tau_{\mathrm{c}, \mathrm{d}}\right)$ was tested in the range $0.005-0.25 \mathrm{~N} \mathrm{~m}^{-2}$ (Van Rijn, 2005); after calibration, we chose to apply a value of $0.15 \mathrm{~N} \mathrm{~m}^{-2}$. The erodibility was set at $10^{-3} \mathrm{~kg} \mathrm{~m}^{-2} \mathrm{~s}^{-1}$.

The efficiency coefficient $E$ was then calculated to quantify the model performance with daily average measured water discharge and sediment concentration in August 2006 upstream (Hanoi, Thuong Cat) and downstream (Nam Dinh, Cua Cam). $E$ values for water discharge in Hanoi, Thuong Cat, Nam Dinh and Cua Cam were 0.75, 0.72, 0.71 and 0.69, respectively. The values for suspended sediment concentrations at the same stations were $0.67,0.66,0.65$ and 0.65 , respectively, thus providing good agreement between measurements and simulations during the main period for sediment transport (i.e. the wet season; Fig. 3).

\section{Results}

\subsection{Water discharge in the main tributaries}

The Red River discharge results from its three major tributaries, the Da, Thao and Lo rivers (Fig. 1). Between 1960 and 2010, the Red River discharge at Son Tay varied from year to year, over the range $80 \times 10^{9} \mathrm{~m}^{3} \mathrm{yr}^{-1}$ (in 2010) to $161 \times 10^{9} \mathrm{~m}^{3} \mathrm{yr}^{-1}$ (in 1971) (Fig. 4), with an average value of $110 \times 10^{9} \mathrm{~m}^{3} \mathrm{yr}^{-1}$. The average annual water discharge was $116 \times 10^{9} \mathrm{~m}^{3} \mathrm{yr}^{-1}$ and $106 \times 10^{9} \mathrm{~m}^{3} \mathrm{yr}^{-1}$ for the periods 1960-1979 and 1989-2010, respectively (Table 1, Figs. 4 and 5a).

The Lo and Thao rivers supply about $50 \%$ of the total water discharge of the Red River, the remaining $50 \%$ being provided by the Da River (Table 1, Fig. 5a). The monthly water discharge of the $\mathrm{Da}$ and Red rivers is highly correlated $(r=0.950)$, as is that of the Red and Duong rivers $(r=0.948)$. As a result, the HBD not only affects the discharge of the Red River, but also that of the Duong River.

The measured yearly water discharge exhibited small increases at each tributary after HBD commissioning (Table 1, Fig. 5a): $7.3 \%$ for the Lo River, $4.6 \%$ for the Thao River and $1.9 \%$ for the Da River. Conversely, while the yearly Red River discharge decreased by $9 \%$ from 116 to $106 \times 10^{9} \mathrm{~m}^{3} \mathrm{yr}^{-1}$, that of the Duong River increased by $14 \%$, from 29.2 to $33.3 \times 10^{9} \mathrm{~m}^{3} \mathrm{yr}^{-1}$. In other words, the portion of discharge diverted by the Duong River increased from $24 \%$ of the Red River before HBD impoundment, to $31 \%$.

Seasonal variations in $Q$ were high. Rainy season (June to October) water discharge represents $71-79 \%$ of the annual total discharge, with only 9-18\% during the dry season (December to April; Table 1). The remaining 5-10\% occurs during the period of lowest rainfall (January, February and March).

Regulation of the HBD has led to changes in the annual water distribution of the Da, Red and Duong rivers. Discharge increased significantly during dry periods post HBD impoundment on the Da River (+48\%, station 3 - see the location in Fig. 1), the Red River (+12\%, station 4) and the Duong River $(+109 \%$, station 5; Table 1) (Fig. 5b). This shows (1) that the HBD has a marked impact on water regulation at the seasonal scale and (2) that the Duong River responds to variations in the Red River, particularly in the dry season in the section above the connection with the ThaiBinh River.

The trends of the inter-annual variability in yearly water discharge are not straightforward. The coefficient of variation, denoted CV and defined as the ratio of standard deviation to the average, is a suitable indicator of variability. While the inter-annual variability did not change for the Red River at Son Tay after HBD impoundment (with a CV of $15 \%$ amongst yearly values), and decreased by only $3 \%$ for the Duong River, it shows higher variations upstream: from 

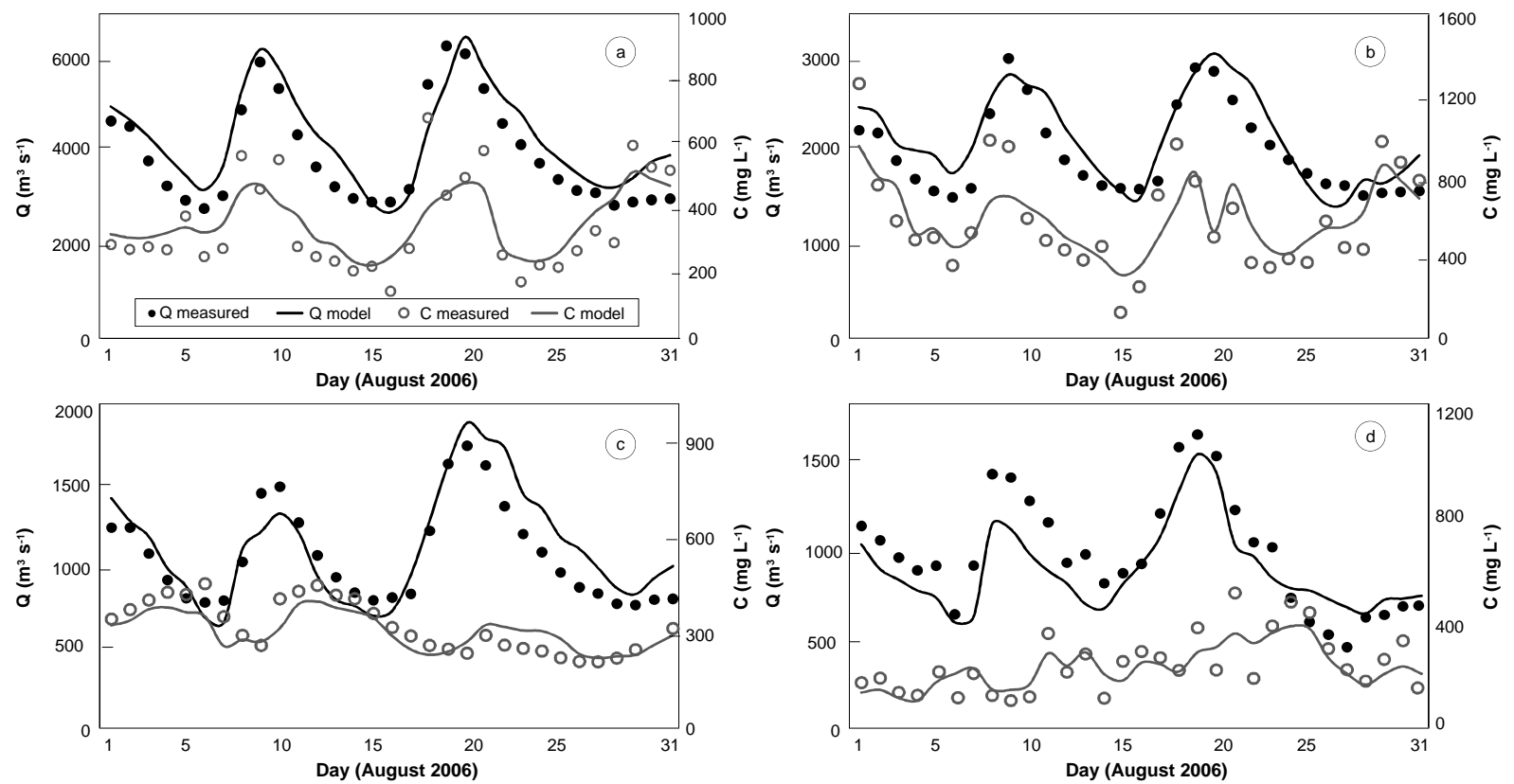

Figure 3. Comparison of modelled and measured water discharge $(Q)$ and suspended sediment concentration $(C)$ in August 2006 (a - Hanoi; b - Thuong Cat; c - Nam Dinh; d - Cua Cam) after calibration of the model.

Table 1. Average water and suspended sediment fluxes obtained from measurements at five gauging stations during the dry season (December-April), the rainy season (June-October), and per year, before (1960-1979) and after (1989-2010) Hoa Binh dam impoundment (see the locations of the stations in Fig. 1).

\begin{tabular}{|c|c|c|c|c|c|c|c|c|}
\hline \multirow[t]{2}{*}{ River } & \multirow[t]{2}{*}{ Station } & \multirow[t]{2}{*}{ Parameter } & \multicolumn{3}{|c|}{$\begin{array}{l}\text { Before Hoa Binh dam } \\
\text { impoundment (1960-1979) }\end{array}$} & \multicolumn{3}{|c|}{$\begin{array}{c}\text { After Hoa Binh dam } \\
\text { impoundment (1989-2010) }\end{array}$} \\
\hline & & & Dry & Rainy & Total year & Dry & Rainy & Total year \\
\hline \multirow[t]{2}{*}{ Lo } & 1 & $Q\left(\times 10^{9} \mathrm{~m}^{3}\right)$ & 4.4 & 22.1 & 30.1 & 5.8 & 22.9 & 32.3 \\
\hline & & $M\left(\times 10^{6} \mathrm{t}\right)$ & 0.2 & 8.3 & 9.2 & 0.4 & 11.6 & 12.7 \\
\hline \multirow[t]{2}{*}{ Thao } & 2 & $Q\left(\times 10^{9} \mathrm{~m}^{3}\right)$ & 4.2 & 17.9 & 25.1 & 4.5 & 18.5 & 26.3 \\
\hline & & $M\left(\times 10^{6} \mathrm{t}\right)$ & 2.0 & 38.7 & 43.5 & 1.4 & 46.4 & 51.7 \\
\hline \multirow[t]{2}{*}{$\mathrm{Da}$} & 3 & $Q\left(\times 10^{9} \mathrm{~m}^{3}\right)$ & 6.6 & 42.8 & 54.5 & 9.8 & 39.5 & 55.5 \\
\hline & & $M\left(\times 10^{6} \mathrm{t}\right)$ & 0.6 & 62.4 & 65.0 & 0.3 & 5.2 & 5.8 \\
\hline \multirow[t]{2}{*}{ Red } & 4 & $Q\left(\times 10^{9} \mathrm{~m}^{3}\right)$ & 16.3 & 86.9 & 116 & 18.2 & 75.2 & 106 \\
\hline & & $M\left(\times 10^{6} \mathrm{t}\right)$ & 3.3 & 108.6 & 119 & 1.9 & 40.3 & 46.0 \\
\hline \multirow[t]{2}{*}{ Duong } & 5 & $Q\left(\times 10^{9} \mathrm{~m}^{3}\right)$ & 2.7 & 22.3 & 29.3 & 5.8 & 23.6 & 33.3 \\
\hline & & $M\left(\times 10^{6} \mathrm{t}\right)$ & 0.5 & 26.1 & 28.9 & 0.7 & 19.2 & 21.6 \\
\hline
\end{tabular}

10 to $18 \%$ for the Da River, from 23 to $15 \%$ for the Lo River, and from 14 to $53 \%$ for the Thao River. The CV of $Q$ in the Da River was multiplied by 1.75 after HBD impoundment.

\subsection{Suspended sediment discharge}

The total suspended sediment discharged from the Red River system depends on water discharge as well as on the suspended sediment concentration of the Lo, Thao and $\mathrm{Da}$ rivers. Before HBD impoundment, $C$ of the Thao River was, on average, $1730 \mathrm{mg} \mathrm{L}^{-1}$, and was always higher than the mean $C$ of the $\mathrm{Da}$ and Lo rivers $\left(1190\right.$ and $306 \mathrm{mg} \mathrm{L}^{-1}$, respectively; Table 2). $C$ of the Red River (at Son Tay) was $1030 \mathrm{mg} \mathrm{L}^{-1}$. The annual total suspended sediment flux increased both in the Lo River (from $9.2 \times 10^{6} \mathrm{tyr}^{-1}$ for the period $1960-1979$ to $12.7 \times 10^{6} \mathrm{tyr}^{-1}$ for the period 1989-2010) and the Thao River (from $43.4 \times 10^{6} \mathrm{tyr}^{-1}$ to $51.7 \times 10^{6} \mathrm{tyr}^{-1}$; Table 1, Fig. 4), whereas sediment discharge and $C$ decreased in the Da and Red rivers (Fig. 5c).

HBD impoundment had a strong effect on sediment discharge and $C$ in the Da, Red and Duong rivers. While the annual total suspended sediment discharge of the Da River was $65.0 \times 10^{6} \mathrm{tyr}^{-1}$ (about half of the total supply to the 


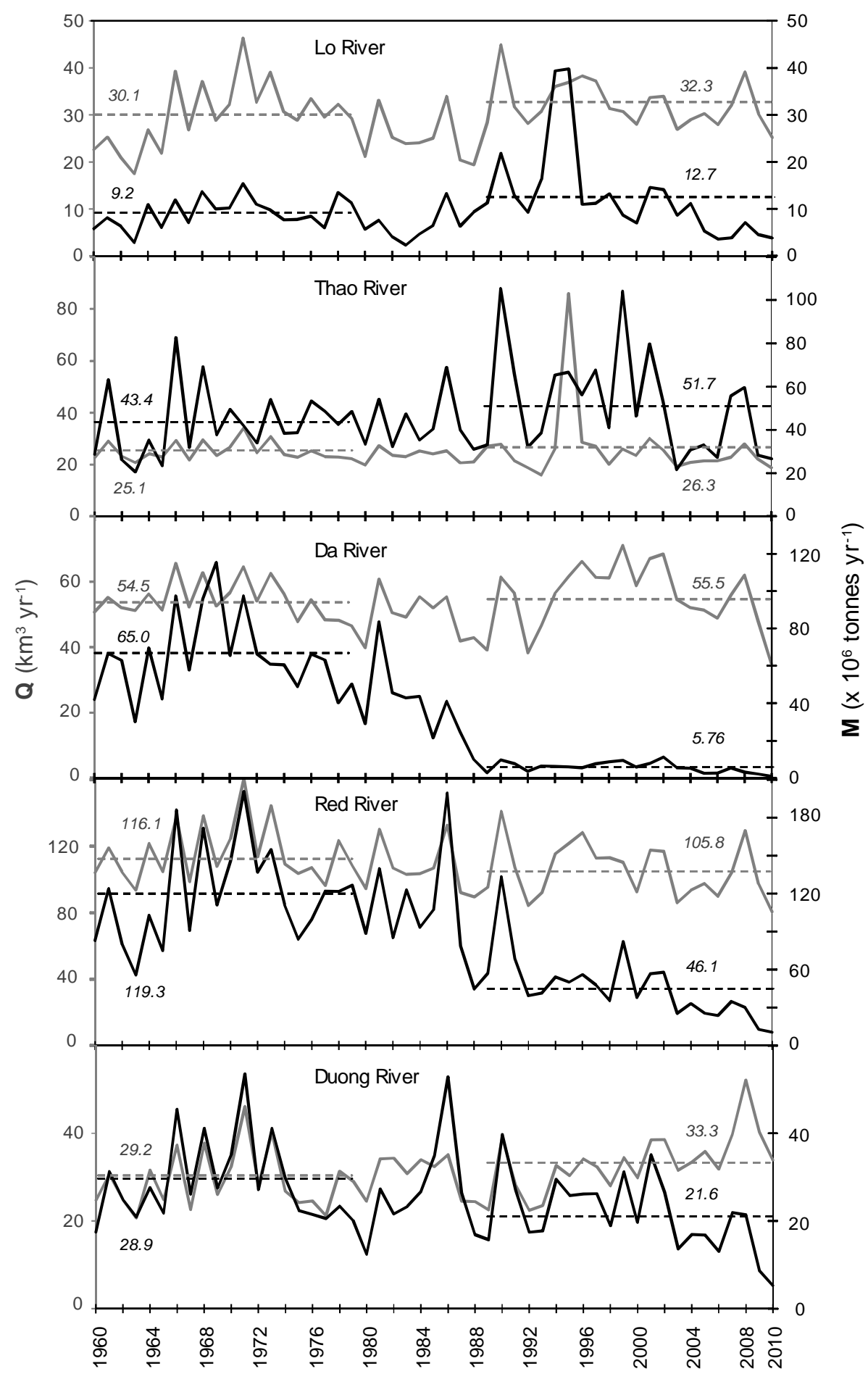

Figure 4. Annual water and suspended sediment discharge in the main tributaries of the Red River system (1960-2010), and average values before and after Hoa Binh dam impoundment.

Red River delta) before HBD impoundment, it dropped to $5.8 \times 10^{6} \mathrm{t} \mathrm{yr}^{-1}$ afterwards ( $-91 \%$ ) (Fig. $5 \mathrm{c}$ ). This is equivalent to only $8 \%$ of the cumulated contributions from the $\mathrm{Da}$, Lo and Thao rivers (Table 1, Fig. 5c). At the Hoa Binh gauging station, the annual average $C$ decreased from
1190 to $106 \mathrm{mg} \mathrm{L}^{-1}$. As a consequence, the annual total suspended sediment of the Red River at Son Tay which averaged $119 \times 10^{6} \mathrm{tyr}^{-1}$ before the HBD was reduced to $46 \times 10^{6} \mathrm{tyr}^{-1}$ after the impoundment $(-61 \%$; see Table 1, Figs. 4 and 5 c), corresponding to a decrease in the 

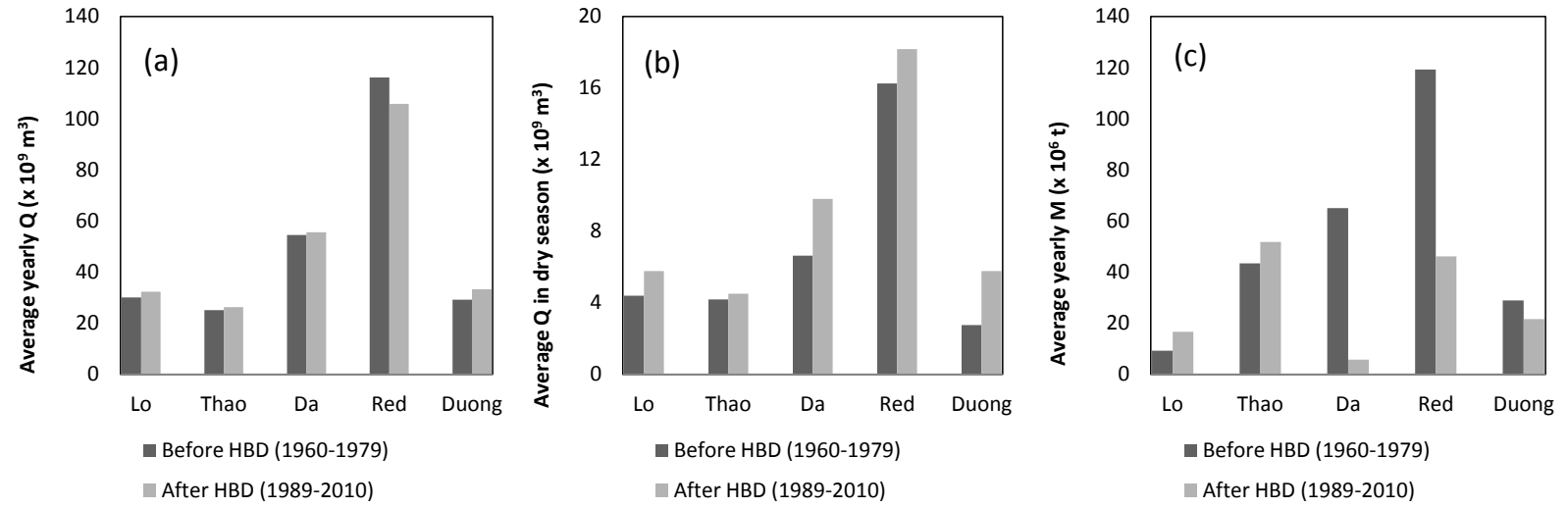

Figure 5. Change in average water and suspended sediment discharge in the main tributaries of the Red River system before and after Hoa Binh dam impoundment: (a) average yearly $Q,(\mathbf{b})$ average $Q$ in the dry season, and (c) average yearly $M$.

Table 2. Average monthly and annual suspended sediment concentrations $\left(\mathrm{mg} \mathrm{L}^{-1}\right)$, and intra-annual variability (coefficient of variation of mean monthly values) obtained from measurements at five gauging stations before (1960-1979) and after (1989-2010) Hoa Binh dam impoundment.

\begin{tabular}{|c|c|c|c|c|c|c|c|c|c|c|c|c|c|c|c|}
\hline \multirow[t]{2}{*}{ River } & \multirow[t]{2}{*}{ Period } & \multicolumn{13}{|c|}{ Monthly averages } & \multirow{2}{*}{$\begin{array}{l}\text { Annual } \\
\text { average }\end{array}$} \\
\hline & & 1 & 2 & 3 & 4 & 5 & 6 & 7 & 8 & 9 & 10 & 11 & 12 & $\begin{array}{l}\mathrm{CV} \\
(\%)\end{array}$ & \\
\hline \multirow[t]{2}{*}{ Lo } & 1960-1979 & 24.1 & 25.1 & 46.7 & 66.8 & 328.6 & 484.7 & 444.0 & 399.4 & 255.3 & 151.1 & 69.4 & 29.5 & 92 & 306 \\
\hline & 1989-2010 & 32.9 & 30.3 & 40.1 & 80.7 & 216.4 & 378.4 & 474.8 & 399.2 & 255.1 & 191.0 & 71.0 & 36.0 & 88 & 421 \\
\hline \multirow[t]{2}{*}{ Thao } & 1960-1979 & 404.8 & 382.2 & 417.7 & 549.7 & 920.7 & 1804.9 & 2426.1 & 2908.8 & 2001.2 & 1225.2 & 868.0 & 521.6 & 80 & 1730 \\
\hline & $1989-2010$ & 324.3 & 270.8 & 314.2 & 523.1 & 1012.7 & 2339.9 & 3150.2 & 2990.7 & 2611.4 & 1413.7 & 1041.0 & 317.3 & 77 & 2060 \\
\hline \multirow[t]{2}{*}{$\mathrm{Da}$} & 1960-1979 & 45.6 & 45.6 & 34.9 & 265.5 & 439.1 & 1249.1 & 1787.9 & 1792.4 & 978.8 & 509.0 & 319.3 & 92.5 & 112 & 1190 \\
\hline & $1989-2010$ & 35.2 & 31.4 & 30.1 & 30.9 & 41.2 & 91.4 & 153.1 & 141.6 & 87.5 & 52.0 & 36.9 & 32.1 & 70 & 106 \\
\hline \multirow[t]{2}{*}{ Red } & 1960-1979 & 183.3 & 163.6 & 156.3 & 211.5 & 538.9 & 1014.0 & 1383.1 & 1468.4 & 1068.6 & 726.2 & 484.9 & 224.6 & 74 & 1030 \\
\hline & 1989-2010 & 101.2 & 93.9 & 91.9 & 117.0 & 262.2 & 427.1 & 480.1 & 606.0 & 577.1 & 338.3 & 252.2 & 96.8 & 68 & 397 \\
\hline \multirow[t]{2}{*}{ Duong } & 1960-1979 & 125.8 & 118.9 & 103.9 & 196.8 & 556.7 & 1028.4 & 1291.1 & 1369.8 & 1025.2 & 713.3 & 452.4 & 180.8 & 80 & 989 \\
\hline & $1989-2010$ & 123.1 & 100.8 & 131.4 & 146.3 & 351.0 & 717.1 & 857.4 & 875.6 & 772.8 & 531.2 & 365.3 & 138.7 & 73 & 738 \\
\hline
\end{tabular}

average $C$ from $1030 \mathrm{mg} \mathrm{L}^{-1}$ to around $400 \mathrm{mg} \mathrm{L}^{-1}$ (Table 2). At Thuong Cat on the Duong River, the annual total suspended sediment which averaged $28.9 \times 10^{6} \mathrm{t} \mathrm{yr}^{-1}$ before the HBD was also reduced to $21.6 \times 10^{6} \mathrm{tyr}^{-1}$ afterwards ( $-17 \%$; see Table 1, Figs. 4 and $5 \mathrm{c})$, and the average $C$ decreased by $25 \%$, from $989 \mathrm{mg} \mathrm{L}^{-1}$ over the period 1960-1979 to $738 \mathrm{mg} \mathrm{L}^{-1}$ over the period 1989-2010 (Table 2). Interestingly, the total suspended sediment delivery in the Duong River slightly increased in the dry season after HBD impoundment, from $0.5 \times 10^{6} \mathrm{tyr}^{-1}$ to $0.7 \times 10^{6} \mathrm{t} \mathrm{yr}^{-1}$ (Table 1).

The seasonal variability of $C$ is high. Total suspended sediment discharge is highest in July and August, and lowest in February and April (Table 2). Suspended sediment discharge for the five months of the rainy season (from June to October) made up 87 to $96 \%$ (Table 1). While the CV amongst the monthly averaged values of $C$ was highest in the Da River (112\%) before HBD impoundment and dropped to $70 \%$ afterwards, it remained unchanged in the Lo and Thao rivers, around 90 and $80 \%$, respectively (Table 2 ). The change in the Da River sediment regime also involved a decrease of
6-7\% in the seasonal variability of $C$ in the Red and Duong rivers.

Despite contrasting changes in the inter-annual variability of river discharge, the main rivers of the Red River system show an enhancement in the variability of relative sediment discharge on the inter-annual scale. While their respective CVs were almost equivalent and ranged from $32 \%$ (Red River at Son Tay) to $36 \%$ (Thao River) before HBD impoundment, they had much higher differences after impoundment, and varied from $39 \%$ in the Duong River to $77 \%$ in the Lo River. Moreover, the absolute change in the standard deviation decreased significantly in the Da River by $88 \%$, in the Red River by $31 \%$, and in the Duong River by $13 \%$, due to a large decrease in the suspended load (Table 2). At the Son Tay station, sediment flux ranged from $56 \times 10^{6} \mathrm{t}$ in 1963 to $201 \times 10^{6} \mathrm{t}$ in 1971 before HBD impoundment and from $10 \times 10^{6} \mathrm{t}$ in 2010 to $134 \times 10^{6} \mathrm{t}$ in 1990 for the period after 1989 . 


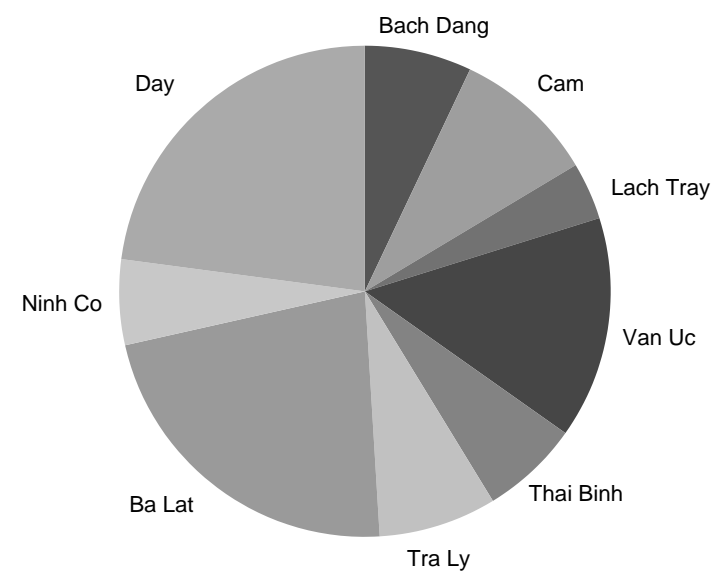

Figure 6. Distribution of water discharge amongst the nine distributaries of the Red River after the Hoa Binh dam impoundment.

\subsection{Influences on the distributary discharge}

The water distribution across the nine river mouths before and after HDB impoundment was estimated from numerical simulations (Table 3). The present calculations show that water distribution was affected by the impoundment of the HBD. The present discharge ratio is shown in Fig. 6. The water discharge ratio of the estuaries in the north of the RRD slightly increased after impoundment: from $15.5 \%$ (before HBD) to $16.5 \%$ for the Cam and Bach Dang estuaries, from 3.5 to $3.7 \%$ for the Lach Tray River, from 13.6 to $14.5 \%$ for the Van Uc River, and from 6.0 to $6.4 \%$ in the Thai Binh River. The water discharge ratio also slightly increased in the Day River, at the south of the delta, from 22.1 to $23 \%$. Conversely, this ratio decreased in the central delta, especially at the Ba Lat mouth, from 24.9 to $22.5 \%$ (Table 3).

The decrease in total water discharge from all the distributaries of $10 \times 10^{9} \mathrm{~m}^{3} \mathrm{yr}^{-1}$ between 1960-1979 and 19892010 (from around 130 to $120 \times 10^{9} \mathrm{~m}^{3} \mathrm{yr}^{-1}$; see Table 3) calculated by the model is due to a decrease in the Red River discharge (Table 1). It should be noted that water use for irrigation, drainage, urban and industrial purposes was not considered in the model. Between the two periods, water discharge of the estuaries increased by $17 \%$ during the dry season (from 17.8 to $20.8 \times 10^{9} \mathrm{~m}^{3}$; see Table 3), while it decreased by $14 \%$ during the rainy season (from 98.8 to $85.2 \times 10^{9} \mathrm{~m}^{3}$; Table 3), due to water regulation by the HBD.

The decrease in suspended sediment concentrations of the Red River caused a strong decrease in suspended sediment concentration as well as suspended sediment discharge in the distributaries. Total suspended sediment delivery decreased both in the dry and rainy seasons after HBD impoundment, from $2.6 \times 10^{6} \mathrm{t}$ to $1.7 \times 10^{6} \mathrm{t}$ for the dry season, and from $77.3 \times 10^{6} \mathrm{t}$ to $30.5 \times 10^{6} \mathrm{t}$ for the rainy season (Table 4). As a result, the total average annual suspended sediment discharge decreased by $59 \%$ after 1989 , from 85 to $35 \times 10^{6} \mathrm{tyr}^{-1}$. The changes in suspended sediment

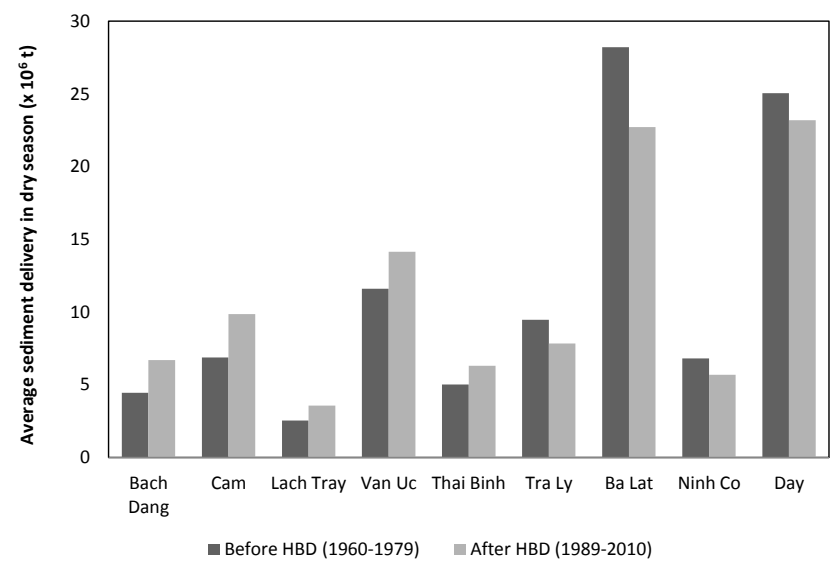

Figure 7. Average sediment delivery in the dry season, per year, at the river mouths of the nine distributaries before and after Hoa Binh dam impoundment.

distribution mirror the changes in discharge distribution; i.e. slight increases in the $M$ ratio were observed in the northern part of the delta (from 15.5 to $17.1 \%$ in the Bach Dang and Cam rivers) and in the southern part (from 22.1 to $22.8 \%$ in the Day River), whereas the $M$ ratio decreased in the central part of the delta. Although the suspended sediment discharge in absolute values decreased in most distributaries, it slightly increased in the northern estuaries (Cam, Bach Dang, Lach Tray, Van Uc, Thai Binh) in the dry season due to an increase in river discharge (Table 4, Fig. 7).

\section{Discussion}

\subsection{Comparison with former studies}

The values of water and sediment discharge calculated in this study from a 50-year data set of discharge and sediment concentration at five key stations of the Red River can be compared with the previously published values. We found an average annual water discharge of $116 \times 10^{9} \mathrm{~m}^{3} \mathrm{yr}^{-1}$ or $3680 \mathrm{~m}^{3} \mathrm{~s}^{-1}$ for the period 1960-1979 and $106 \times 10^{9} \mathrm{~m}^{3} \mathrm{yr}^{-1}$ or $3350 \mathrm{~m}^{3} \mathrm{~s}^{-1}$ for 1989-2010 (Table 1, Fig. 4). These values are consistent with the previous estimates of Dang et al. (2010), $3557 \mathrm{~m}^{3} \mathrm{~s}^{-1}$ for $1960-1988$ and $3426 \mathrm{~m}^{3} \mathrm{~s}^{-1}$ for 1989-2006, and those of other reports or papers (To, 2000; Nguyen et al., 2003; Le et al., 2005). This is to be expected, as all estimations were based on data provided by the same administration.

The value of $31 \%$ of water diverted by the Duong River and calculated over 22 years is in very good agreement with the former estimate over 11 years (1996-2006) by Luu et al. (2010), who calculated an average diversion of $30 \%$, with variations from $25 \%$ during the wetter period 1996-2000 to $35 \%$ during the drier 2001-2006 period. Although the HBD does not influence yearly water discharge, its regulation has 
Table 3. Average water discharge in the nine distributaries of the Red River obtained from numerical simulations in the dry season (December-April), in the rainy season (June-October), and per year, before (1960-1979) and after (1989-2010) Hoa Binh dam impoundment; comparison with previous estimates (Pruszak et al., 2005; Luu et al., 2010).

\begin{tabular}{|c|c|c|c|c|c|c|c|c|c|c|}
\hline \multirow[t]{2}{*}{ River mouth } & \multirow[t]{2}{*}{$\begin{array}{l}\text { Water } \\
\text { delivery }\end{array}$} & \multicolumn{3}{|c|}{$\begin{array}{l}\text { Before Hoa Binh dam } \\
\text { impoundment (1960-1979) }\end{array}$} & \multicolumn{3}{|c|}{$\begin{array}{c}\text { After Hoa Binh dam } \\
\text { impoundment (1989-2010) }\end{array}$} & \multirow[t]{2}{*}{$\begin{array}{c}P^{*} \\
2005\end{array}$} & \multicolumn{2}{|c|}{ Luu et al. (2010) } \\
\hline & & $\begin{array}{r}\text { Dry } \\
\text { season }\end{array}$ & $\begin{array}{l}\text { Rainy } \\
\text { season }\end{array}$ & $\begin{array}{l}\text { Total } \\
\text { year }\end{array}$ & $\begin{array}{r}\text { Dry } \\
\text { season }\end{array}$ & $\begin{array}{l}\text { Rainy } \\
\text { season }\end{array}$ & $\begin{array}{l}\text { Total } \\
\text { year }\end{array}$ & & $\begin{array}{c}2006 \\
\text { (dry year) }\end{array}$ & $\begin{array}{c}1996 \\
\text { (wet year) }\end{array}$ \\
\hline \multirow[t]{2}{*}{ Bach Dang } & $Q\left(\times 10^{9} \mathrm{~m}^{3}\right)$ & 0.8 & 6.4 & 8.0 & 1.4 & 6.0 & 8.4 & & & \\
\hline & $Q$ ratio (\%) & 4.5 & 6.5 & 6.1 & 6.7 & 7.0 & 6.9 & & & \\
\hline \multirow[t]{2}{*}{ Cam } & $Q\left(\times 10^{9} \mathrm{~m}^{3}\right)$ & 1.2 & 10.0 & 12.2 & 2.0 & 8.0 & 11.5 & & & \\
\hline & $Q$ ratio $(\%)$ & 6.9 & 10.0 & 9.4 & 9.9 & 9.4 & 9.5 & & & \\
\hline \multirow[t]{2}{*}{ Lach Tray } & $Q\left(\times 10^{9} \mathrm{~m}^{3}\right)$ & 0.5 & 3.7 & 4.6 & 0.7 & 3.2 & 4.5 & & & \\
\hline & $Q$ ratio $(\%)$ & 2.5 & 3.7 & 3.5 & 3.6 & 3.8 & 3.7 & & & \\
\hline \multirow[t]{2}{*}{ Van Uc } & $Q\left(\times 10^{9} \mathrm{~m}^{3}\right)$ & 2.1 & 13.9 & 17.7 & 2.9 & 12.5 & 17.5 & & & \\
\hline & $Q$ ratio $(\%)$ & 11.6 & 14.1 & 13.6 & 14.1 & 14.6 & 14.5 & & & \\
\hline Sub-total NE & $Q$ ratio (\%) & 25.5 & 34.2 & 32.6 & 34.3 & 34.8 & 34.7 & 26.0 & 34.6 & 26.1 \\
\hline \multirow[t]{2}{*}{ Thai Binh } & $Q\left(\times 10^{9} \mathrm{~m}^{3}\right)$ & 0.9 & 6.2 & 7.8 & 1.3 & 5.5 & 7.7 & & & \\
\hline & $Q$ ratio $(\%)$ & 5.0 & 6.2 & 6.0 & 6.3 & 6.5 & 6.4 & 11.0 & & \\
\hline \multirow[t]{2}{*}{ Tra Ly } & $Q\left(\times 10^{9} \mathrm{~m}^{3}\right)$ & 1.7 & 8.0 & 10.9 & 1.6 & 6.6 & 9.3 & & & \\
\hline & $Q$ ratio $(\%)$ & 9.5 & 8.1 & 8.4 & 7.8 & 7.7 & 7.8 & 10.0 & & \\
\hline \multirow[t]{2}{*}{ Ba Lat } & $Q\left(\times 10^{9} \mathrm{~m}^{3}\right)$ & 5.0 & 23.8 & 32.5 & 4.7 & 19.1 & 27.0 & & & \\
\hline & $Q$ ratio $(\%)$ & 28.2 & 24.1 & 24.9 & 22.7 & 22.4 & 22.5 & 25.0 & & \\
\hline \multirow[t]{2}{*}{ Ninh Co } & $Q\left(\times 10^{9} \mathrm{~m}^{3}\right)$ & 1.2 & 5.8 & 7.8 & 1.2 & 4.8 & 6.8 & & & \\
\hline & $Q$ ratio $(\%)$ & 6.8 & 5.8 & 6.0 & 5.7 & 5.6 & 5.6 & 6.0 & & \\
\hline Sub-total centre & $Q(\%)$ & 49.5 & 44.4 & 45.3 & 42.5 & 42.3 & 42.3 & 52.0 & 44.6 & 56.7 \\
\hline \multirow[t]{2}{*}{ Day } & $Q\left(\times 10^{9} \mathrm{~m}^{3}\right)$ & 4.4 & 21.2 & 28.8 & 4.8 & 19.5 & 27.6 & & & \\
\hline & $Q$ ratio $(\%)$ & 25.1 & 21.4 & 22.1 & 23.2 & 22.9 & 23.0 & 22.0 & 20.8 & 17.2 \\
\hline Total & $Q\left(\times 10^{9} \mathrm{~m}^{3}\right)$ & 17.8 & 98.8 & 130.5 & 20.8 & 85.2 & 120.3 & & 100.1 & \\
\hline
\end{tabular}

modified the range of seasonal variation. Water discharge increased by $48 \%$ in the dry season in the Da River, by $12 \%$ in the Red River and by $109 \%$ in the Duong River (Fig. 5b).

No estimates of water distribution amongst the nine estuaries have been published for the period before HBD impoundment. However, Pruszak et al. (2005) gave estimates of the water discharge percentage for six estuaries, which are reported in Table 3. The date is not given, but they probably refer to the pre-1989 period, as they consider a global yearly suspended sediment flux of $116 \times 10^{6} \mathrm{tyr}^{-1}$. Their percentage for the Van Uc-Thai Binh system (37\%) is very close to our estimate before 1979 for the whole DuongThai Binh system (38.6\% for Cam, Bach Dang, Lach Tray, Van Uc and Thai Binh), and for Tra Ly as well (10\% by Pruszak et al., 2005, versus $8.4 \%$ in our calculation). The estimates for the Ba Lat, Ninh Co and Day estuaries are the same, and represent about 25, 6 and $22 \%$, respectively. Our value for $\mathrm{Ba}$ Lat is also consistent with that of van Maren and
Hoekstra (2004): $21 \%$. Other calculations were performed by Luu et al. (2010, see Table 3), for a dry year (2006) and a wet year (1996) post 1989, while ours were calculated for an average post-1989 year. The percentages of Luu et al. (2010) for the three main outlets are very close to our estimates, with those for dry years being in better agreement with our estimates than for the wet years.

Concerning the suspended sediment discharge, it should be noted that there were large increases in sediment discharge and concentration in the Thao and Lo rivers. These were partly caused by human activities in the Chinese part of the Red River (Yuanjiang River), as illustrated by the average $C$ at the Manhao station during the 1960s, 1970s, 1980s and 1990 s, where values of $1870,2490,3120$ and $3630 \mathrm{mg} \mathrm{L}^{-1}$, respectively, were observed (He et al., 2007). Other impacts in China and in Vietnam such as shifts in land use and deforestation may also contribute to these changes. 
Table 4. Average suspended sediment fluxes in the nine distributaries of the Red River obtained from numerical simulations in the dry season (December-April), the rainy season (June-October), and per year, before (1960-1979) and after (1989-2010) Hoa Binh dam impoundment.

\begin{tabular}{|c|c|c|c|c|c|c|c|}
\hline \multirow[t]{2}{*}{ River mouth } & \multirow[t]{2}{*}{$\begin{array}{l}\text { Sediment } \\
\text { delivery }\end{array}$} & \multicolumn{3}{|c|}{$\begin{array}{c}\text { Before Hoa Binh dam } \\
\text { impoundment (1960-1979) }\end{array}$} & \multicolumn{3}{|c|}{$\begin{array}{c}\text { After Hoa Binh dam } \\
\text { impoundment (1989-2010) }\end{array}$} \\
\hline & & $\begin{array}{r}\text { Dry } \\
\text { season }\end{array}$ & $\begin{array}{l}\text { Rainy } \\
\text { season }\end{array}$ & $\begin{array}{l}\text { Total } \\
\text { year }\end{array}$ & $\begin{array}{r}\text { Dry } \\
\text { season }\end{array}$ & $\begin{array}{l}\text { Rainy } \\
\text { season }\end{array}$ & $\begin{array}{l}\text { Total } \\
\text { year }\end{array}$ \\
\hline \multirow[t]{2}{*}{ Bach Dang } & $M\left(\times 10^{6} \mathrm{t}\right)$ & 0.1 & 4.8 & 5.2 & 0.1 & 2.1 & 2.4 \\
\hline & $M$ ratio $(\%)$ & 3.5 & 6.2 & 6.1 & 6.6 & 6.9 & 6.9 \\
\hline \multirow[t]{2}{*}{ Cam } & $M\left(\times 10^{6} \mathrm{t}\right)$ & 0.1 & 7.4 & 8.0 & 0.2 & 3.1 & 3.6 \\
\hline & $M$ ratio $(\%)$ & 5.4 & 9.6 & 9.4 & 10.2 & 10.2 & 10.2 \\
\hline \multirow[t]{2}{*}{ Lach Tray } & $M\left(\times 10^{6} \mathrm{t}\right)$ & 0.1 & 2.8 & 3.0 & 0.1 & 1.1 & 1.3 \\
\hline & $M$ ratio $(\%)$ & 2.3 & 3.6 & 3.5 & 4.2 & 3.7 & 3.7 \\
\hline \multirow[t]{2}{*}{ Van Uc } & $M\left(\times 10^{6} \mathrm{t}\right)$ & 0.3 & 10.7 & 11.5 & 0.2 & 4.4 & 5.1 \\
\hline & $M$ ratio $(\%)$ & 10.7 & 13.8 & 13.6 & 14.5 & 14.4 & 14.4 \\
\hline \multirow[t]{2}{*}{ Thai Binh } & $M\left(\times 10^{6} \mathrm{t}\right)$ & 0.1 & 4.7 & 5.1 & 0.1 & 2.0 & 2.2 \\
\hline & $M$ ratio $(\%)$ & 4.6 & 6.1 & 6.0 & 6.0 & 6.4 & 6.4 \\
\hline \multirow[t]{2}{*}{ Tra Ly } & $M\left(\times 10^{6} \mathrm{t}\right)$ & 0.3 & 6.4 & 7.1 & 0.1 & 2.4 & 2.7 \\
\hline & $M$ ratio (\%) & 10.0 & 8.3 & 8.4 & 7.8 & 7.7 & 7.7 \\
\hline \multirow[t]{2}{*}{ Ba Lat } & $M\left(\times 10^{6} \mathrm{t}\right)$ & 0.8 & 19.0 & 21.1 & 0.4 & 6.8 & 7.8 \\
\hline & $M$ ratio (\%) & 29.9 & 24.6 & 24.9 & 22.3 & 22.3 & 22.3 \\
\hline \multirow[t]{2}{*}{ Ninh Co } & $M\left(\times 10^{6} \mathrm{t}\right)$ & 0.2 & 4.6 & 5.1 & 0.1 & 1.7 & 2.0 \\
\hline & $M$ ratio (\%) & 7.3 & 5.9 & 6.0 & 5.4 & 5.6 & 5.6 \\
\hline \multirow[t]{2}{*}{ Day } & $M\left(\times 10^{6} \mathrm{t}\right)$ & 0.7 & 16.9 & 18.8 & 0.4 & 7.0 & 8.0 \\
\hline & $M$ ratio (\%) & 26.4 & 21.8 & 22.1 & 22.9 & 22.8 & 22.8 \\
\hline Total & $M\left(\times 10^{6} \mathrm{t}\right)$ & 2.6 & 77.3 & 84.8 & 1.7 & 30.5 & 35.1 \\
\hline
\end{tabular}

The average sediment flux in Hanoi before the HBD $\left(119 \times 10^{6} \mathrm{t} \mathrm{yr}^{-1}\right)$ calculated over $1960-1979$ is the same as that calculated by Dang et al. (2010). It is also in good agreement with other previous estimates that ranged from 100 to $160 \times 10^{6} \mathrm{tyr}^{-1}$, with a very close estimate $\left(116 \times 10^{6} \mathrm{tyr}^{-1}\right)$ given by Pruszak et al. (2005). The value calculated for $1989-2010\left(46 \times 10^{6} \mathrm{tyr}^{-1}\right)$ is also very close to the value calculated by Dang et al. (2010) $\left(49 \times 10^{6} \mathrm{t} \mathrm{yr}^{-1}\right)$ for the period 1979-2008. The inter-annual variability of sediment transport in Hanoi was higher over the 1960-1979 period (range in yearly values 56$201 \times 10^{6} \mathrm{tyr}^{-1}$, standard deviation $38.4 \times 10^{6} \mathrm{tyr}^{-1}$ ) than during the 1989-2010 period $\left(10-134 \times 10^{6} \mathrm{t} \mathrm{yr}^{-1}\right.$, standard deviation $26.3 \times 10^{6} \mathrm{t} \mathrm{yr}^{-1}$ ). This latter range is consistent with the range estimate from 30 to $120 \times 10^{6} \mathrm{t}$ as quoted by van den Bergh et al. (2007b), although we found a smaller lower limit due to the recent lower sediment discharge (24 $\times 10^{6} \mathrm{t} \mathrm{yr}^{-1}$ on average for 2003-2010; see Fig. 4).

After HBD impoundment, average daily $C$ decreased from 1190 to $106 \mathrm{mg} \mathrm{L}^{-1}$ at Hoa Binh (Da River) and from $1030 \mathrm{mg} \mathrm{L}^{-1}$ to around $400 \mathrm{mg} \mathrm{L}^{-1}$ at the Son Tay station on the Red River. The annual total suspended sediment discharge, which was $65 \times 10^{6} \mathrm{t} \mathrm{yr}^{-1}$ in the Da River and represented about half of the total supply to the Red River, decreased to $5.8 \times 10^{6} \mathrm{tyr}^{-1}$. This decrease of $91 \%$ is consistent with an estimated sediment efficiency trapping of $88 \%$ in the HBD (Dang et al., 2010).

The highest value at the Thuong Cat station as compared to the Son Tay station may be explained by either new sediment inputs between the two stations (from urban, industrial or agricultural origins or from dredging activities such as observed in Hanoi), or by riverbed and bank erosion induced by the local river load capacity (Ouillon and Le Guennec, 1996; van Rijn, 2005).

The distribution of sediment discharge from the Red River to the RRD coast changed both spatially and quantitatively, decreasing from $85 \times 10^{6}$ to $35 \times 10^{6}$ t per year (about $59 \%$ ). If we consider the 1989-2010 period, $50 \%$ of the sediment brought by the Lo, Thao and Da rivers which did not reach the river mouths settled in the delta. Between Hanoi and the sea, $11 \times 10^{6} \mathrm{t}$ settle per year, representing $31 \%$ of the sediment discharge at Son Tay, the remaining part being delivered to the ocean. This percentage is similar to that of 1960-1979 (29\%); however, the absolute quantity is divided 
by 3 . This estimate should be considered to be a first guess, since the model does not take flocculation or stratification into account, and only one sediment class. However, it is consistent with the value of $70 \%$ of sediment delivered to the sea as estimated by Häglund and Svensson (2002).

\subsection{Enhanced estuarine deposition}

Recently, enhanced deposition occurred in the middle estuaries, in particular the Cam-Bach Dang, Ninh Co and Day rivers, resulting in a need for increased dredging in order to improve navigability. In the Ninh Co and Day rivers, projects have been set up to improve navigability. The recent changes in the volume of sediment dredged from the estuarine harbour of Haiphong illustrate the enhanced silting up of the Cam-Bach Dang estuary. The dredged volumes of sediment in the port of Haiphong in 1922, 1983 and 1992 were $922.6,1256$ and $1700 \times 10^{3} \mathrm{~m}^{3}$, respectively. Nowadays, $4-5 \times 10^{6} \mathrm{t}\left(1600-2000 \times 10^{3} \mathrm{~m}^{3}\right)$ of sediments are dredged annually from the port in order to guarantee port activities (Vietnam Administration of Haiphong, unpublished). These measurements show that, although sediment delivery decreased after HBD impoundment, siltation recently increased in the Haiphong harbour, i.e. in the estuary of the Cam-Bach Dang River. Which process(es) could explain such an apparent paradox?

Flocculation of estuarine suspended particulate matter is strongly dependent on the suspended sediment concentration, especially in low energetic episodes characteristic of slack water periods (i.e. with a Kolmogorov microscale greater than $1000 \mu \mathrm{m}$ ) (Verney et al., 2009), and turbulence has been identified as the most important factor controlling aggregation in the wet season in the Bach Dang estuary (Lefebvre et al., 2012). Apart from the sediment load, sediment deposition in the estuary is governed by hydrodynamics ( $Q$ and turbulence). As examined by Lefebvre et al. (2012), tidal pumping is a key process in sediment dynamics and deposition in the Cam-Bach Dang estuary, especially during the dry season, when deposition in the middle and lower estuaries is three times higher than during the wet season. Tidal pumping occurs under two conditions: (1) $Q$ must be low enough so that marine water flows into the estuary during flood, and (2) $Q$ must be high enough so that the tidal cycle shows a strong velocity asymmetry, with a short but highly energetic flood period. Tidal pumping is probably higher in the northeast of the delta (the Cam-Bach Dang, Lach Tray and Van Uc estuaries) than in the central and southern delta estuaries, because the tidal amplitude is much higher there (Uncles et al., 2002) (see the amplitudes in Sect. 2.4).

In this context, two possible origins of enhanced siltation caused by the new water regulation can be envisaged: (a) lower discharges in the wet period, and (b) higher discharges in the dry season. (a) By limiting flow during floods, the HBD regulation decreased the sediment transport capacity of the rivers - especially in the higher floods that flushed the river bed - thereby enhancing deposition in the river, with the knock-on effect of obstructing the boat traffic and the outgoing tidal waters (Tran et al., 2002). (b) The observed slight increase in river discharge during the dry season after the impoundment of the HBD (Red and Duong rivers, Fig. 5b) likely enhanced the tidal asymmetry and the associated tidal pumping (Allen et al., 1980; Dyer, 1986). Mechanisms (a) and (b) may be superimposed. However, as shown in Lefebvre et al. (2012), deposition in the estuary mainly occurs in the dry season. The changes in $Q$, turbulence and $C$ variability caused by dam regulation and dam retention may have moved the turbidity maximum zone in the dry season.

Unfortunately, no data are available on the location of the extreme turbidity maximum before HBD impoundment, and we are not able to assess if the extreme turbidity maximum in the northern branch of the Red River estuary moved after the impoundment of the HBD towards the harbour estuarine area. The combination of a new water regulation and tidal pumping is a possible origin of this increased siltation. This hypothesis is only an assumption, opening up new avenues of research.

\subsection{Erosion and/or accretion along the Red River delta}

During the last geological period, the Van Uc, Thai Binh, Tra Ly and Ba Lat mouths had very rapid accretion zones, with sediment accumulation rates exceeding sea level rise (1$\left.2 \mathrm{~mm} \mathrm{yr}^{-1}\right)$ and tectonic subsidence $\left(2 \mathrm{~mm} \mathrm{yr}^{-1}\right.$; Do et al., 2007). Typical mechanisms of delta progradation involve the forming and connecting of sand bars in front of the mouths (Do et al., 2012), thus inducing a progressive development of the delta outward into the Gulf of Tonkin. Recently, the shorelines at these river mouths have been expanding at a rate of about $15-100 \mathrm{~m} \mathrm{yr}^{-1}$, and the rapid accretion in front of the river mouths caused widespread difficulties for navigation, similar to the Haiphong bay. Conversely, sediment deficits in the adjacent areas led to shoreline erosion. Coastal erosion causes loss of land and the expansion of saline intrusions. The coastal zones where rapid erosion prevails are located from south of the Ba Lat mouth to the Hai Hau district (see location in Fig. 1), and in the nearby mouths (Do et al., 2012), such as north of the Ninh Co mouth. Shoreline regression in Hai Hau can reach $15 \mathrm{~m} \mathrm{yr}^{-1}$. Shoreline changes obtained from maps suggest that the Hai Hau erosion started around the beginning of the twentieth century, with a decrease in erosion rates during the late 1960s. According to geodesic measurements from 1963 to 1985, the Hai Hau district was subsiding at a maximum rate of up to $5 \mathrm{~mm} \mathrm{yr}^{-1}$ (van den Bergh et al., 2007a). Sediments from the Red River (Ba Lat) are largely transported in a southerly direction and do not reach the coastline of the Hai Hau district. Shoreline erosion also takes place north of the Van Uc River (Haiphong), although with lower intensity. The reduction in sediments exported to the coastal zone due to trapping in the HBD has already been identified as the main cause of 
intensified erosion in the RRD coastal line (Tran et al., 2002; Do et al., 2007, 2012).

To distinguish between various erosion levels, the intensity of erosion was denoted as "weak" (less than $2.5 \mathrm{~m} \mathrm{yr}^{-1}$ ), "mean" (2.5 to $5 \mathrm{~m} \mathrm{yr}^{-1}$ ), and "strong" erosion (more than $10 \mathrm{~m} \mathrm{yr}^{-1}$ ) by Tran et al. (2002). In the period 1965-1990, the length of eroded coastline was $59 \mathrm{~km}$, with a mean intensity covering $45.5 \%$ of the shoreline and a strong intensity covering $45.5 \%$. For the period 1991-1995, the length of eroded coastline decreased to $25.5 \mathrm{~km}$ due to dike consolidation and because sections in Bang La (northeast of the Van Uc River mouth) and Tien Lang (southwest of the Van Uc River mouth) switched from erosion to accretion. However, strong intensity covered up to $87.5 \%$ of the shoreline for this period. The Hai Hau coast became the main eroded coastline, with an average erosion rate of $8.3 \mathrm{~m} \mathrm{yr}^{-1}$ in the period 1965-1991 and up to $15.0 \mathrm{~m} \mathrm{yr}^{-1}$ for 1991-1995 (Tran et al., 2001).

In the coastal area, recent measurements of the sedimentation rate at the outer Tra Ly mouth based on the analysis of ${ }^{210} \mathrm{~Pb}$ in sediment cores show that the sediment rate in this area is decreasing (Bui et al., 2012). At $10 \mathrm{~m}$ in depth in front of the river mouth (station HP4 in Bui et al., 2012), the average sedimentation rate for the periods 1966-1975, 1975-1988 and 1988-2011 was 1.8, 1.24 and $1.01 \mathrm{~cm} \mathrm{yr}^{-1}$, respectively. Further offshore (at about $20 \mathrm{~m}$ in depth, HP6), the average sedimentation rate for the periods 1964-1976, 1976-1984 and 1984-2011 was 0.67, 1.0 and $0.56 \mathrm{~cm} \mathrm{yr}^{-1}$, respectively. This tendency is coincident with the reduction in sediment input from the Red River to the sea after HBD impoundment.

In order to assess the impacts of the HBD on the distribution of suspended sediment along the Red River delta, an integrated model (hydrodynamic-wave-sediment transport) was set up with different scenarios, before and after the HBD period ( $\mathrm{Vu}$ et al., 2011). This model did not take into account the influence of polysaccharide polymers (extra-cellular polymeric substances, EPS) in the aggregation, which have been shown to be efficient in the Cam-Bach Dang estuary (Mari et al., 2012). The simulations show that, in the Haiphong bay area and during the wet season, the averaged $C$ at water depths of less than 5, 5-10, 10-15, 15-20, 20-25, and 30-35 $\mathrm{m}$ decreased by $62,66,65,54,42$, and $36 \%$, respectively, after HDB impoundment. In front of the Ba Lat mouth and during the wet season, averaged $C$ at water depths less than 5, 5-10, and 10-15 m decreased by 63, 56 , and $39 \%$, respectively. These results show that the reduction in sediment delivery has a higher impact on shallow water areas, up to $15 \mathrm{~m}$ in the north and up to $10 \mathrm{~m}$ in front of the central delta, where morphologic changes are driven by wave action more than by tidal asymmetry (van Maren et al., 2004).

\subsection{Boundary conditions}

Although the value of $50 \mathrm{mg} \mathrm{L}^{-1}$ fixed at the river mouth during flood periods enabled the calculation of estimates of sediment flux, this arbitrary value likely underestimates the sediment flux from offshore to the estuary, and thus estuarine siltation. To improve the accuracy of sediment flux estimates, the measurement of $C$ at river mouths during flood tides is strongly encouraged in future work. The coupling of the river basin model to a coastal hydro-sedimentary model should allow better estimation of estuarine deposition rates, and estimations of erosion and accretion rates along the delta as well, enabling a closer analysis in regards to the available measurements.

\section{Conclusions}

Although the estimates of water and sediment discharge can be improved in the future (e.g. measuring $C$ at the river mouths during flood periods, taking into account bedload transport and several classes of suspended particles as well in the model, connecting the river basin model to a 2-D or 3-D coastal hydro-sedimentary model, etc.), this paper is the first to provide the distribution of water and sediments within the nine distributaries of the Red River, one of the biggest rivers in the world (ranked 9th by Milliman and Meade in 1983 in terms of sediment input to the ocean). The fluxes were estimated before and after the Hoa Binh dam impoundment, and compared.

The estuaries of the Red River delta are presently silting up, and this is partly due to the water flow regulation of the HBD, which has led to a decrease in sediment transport capacity and an increase in river discharge in the northern delta during the dry season, all of which likely enhance deposition in the Cam-Bach Dang estuary. Moreover, the decrease in the suspended sediment discharge of the Red River induced a decrease in the sedimentation rate along the delta shoreline. Coastal erosion intensifies when sedimentation and accumulation no longer balance sea level rise and tectonic subsidence, and this factor needs to be taken into account when considering dam regulation. The increase in the suspended sediment discharge ratio in the northern (Cam, Bach Dang, Lach Tray, Van Uc, Thai Binh) and southern estuaries (Day) and its decrease at the Ba Lat, Tra Ly and Ninh Co mouths influenced not only erosion and accretion zones along the RRD coasts, but also altered the geological, morphological, biogeochemical and ecological responses in the estuaries, deltas and coastal areas (e.g. Rochelle-Newall et al., 2011; Bui et al., 2012; Navarro et al., 2012).

River dams have been built in Vietnam for many decades for energy supply, such as the Day dam in 1937 (on the Day River), the Thac Ba dam in 1970 (on the Chay River), and the HBD in 1989. Sediment trapping in the reservoirs was not considered during the first decades. However, recent 
studies have documented their impacts on sediment fluxes. Even if the Hoa Binh dam has played a considerable role in flood control, irrigation and electricity production in northern Vietnam, this study shows that it also significantly affected water discharge and the suspended sediment input from the Red River basin to the delta and coastal areas. Finally, this work underlines the need for an integrated management plan that extends from the river basin to the coastal zone and that involves the close collaboration of hydrologists, coastal oceanographers, and decision makers.

Acknowledgements. This work was financed by the science and technological cooperation programme between the Vietnam Academy of Sciences and Technology (VAST) and the French Research Institute for Development (IRD), VAST.HTQT.Phap.01/1415. It benefited also from the support given by USTH to the VIETNAMINS project, and from the UMR LEGOS and VAST.ĐLT.05/14-15 project. J. Shaw and M. Sassi are thanked for their reviews and comments on previous versions of this paper. The editor, Paola Passalacqua, is gratefully acknowledged. A native English speaker, Emma Rochelle-Newall, is warmly thanked for English corrections.

Edited by: P. Passalacqua

\section{References}

Achite, M. and Ouillon, S.: Suspended sediment transport in a semiarid watershed, Wadi Abd, Algeria (1973-1995), J. Hydrol., 343, 187-202, 2007.

Allen, G. P., Salomon, J. C., Bassoulet, P., du Penhoat, Y., and de Grandpre, C.: Effects of tides on mixing and suspended sediment transport in macrotidal estuaries, Sediment. Geol., 26, 69-90, 1980.

Bui, V. V., Liu, Z. F., Tran, D. T., Tran, D., Lan, C.-A., Huh, T. S., Nguyen, H., Cu, D., Nguyen, H. N., Quan, V., and Huy, D. V.: Sedimentation rate and geochronology of sediments in the nearshore zone of the Red River delta: evidence from the ${ }^{210} \mathrm{~Pb}$ and ${ }^{137} \mathrm{Cs}$ radiotracer, Mar. Res. Env., tome XVII, Publishing House for Science and Technology, Hanoi, 59-70, 2012.

Chow, V. T.: Open Channel Hydraulics, McGraw-Hill Book Co., New York, NY, 680 pp., 1959.

Dang, T. H.: Erosion et transferts de Matières En Suspension, carbone et métaux dans le basin versant du Fleuve Rouge depuis la frontière sino-vietnamienne jusqu'à l'entrée du delta, Ph.D. thesis, University of Bordeaux 1, Bordeaux, 309 pp. + appendix, available at: http://ori-oai.u-bordeaux1.fr/ pdf/2011/DANG_THIHA2011.pdf, 2011.

Dang, T. H., Coynel, A., Orange, D., Blanc, G., Etcheber, H., and Le, L. A.: Long-term monitoring (1960-2008) of the riversediment transport in the Red River Watershed (Vietnam): Temporal variability and dam-reservoir impact, Sci. Total Environ., 408, 4654-4664, 2010.

DHI: A Modeling System for Rivers and Channels, MIKE11 Reference Manual, Hørsholm, Denmark, 2009.
Do, M. D., Mai, T. N., Chu, V., Ngoi, T., Nghi, D., Tien, M., van Weering, T. C. E., and van den Bergh, G. D.: Sediment distribution and transport at the nearshore zone of the Red River delta, Northern Vietnam, J. Asian Earth Sci., 29, 558-565, 2007.

Do, M. D., Mai, T. N., and Chu, V. N.: An analysis of coastal erosion in the tropical rapid accretion delta of the Red River, Vietnam, J. Asian Earth Sci., 43, 98-109, 2012.

Dronkers, J.: Tide-induced residual transport of fine sediment, in: Physics of shallow estuaries and bays, Lecture notes Coast. Estuar. Studies, Vol. 16, edited by: van de Kreeke, J., Springer, Berlin, 228-244, 1986.

Dyer, K. R.: Coastal and Estuarine Sediment Dynamics, Wiley, Chichester, 342 pp., 1986.

Etemad-Shahidi, A., Shahkolahi, A., and Liu, W.-C.: Modeling of hydrodynamics and cohesive sediment processes in an estuarine system: Study case in Danshui river, Environ. Model. Assess., 15, 261-271, 2010.

Fang, G., Kwok, Y. K., Yu, K., and Zhu, Y.: Numerical simulation of principal tidal constituents in the South China Sea, Gulf of Tonkin and Gulf of Thailand, Cont. Shelf Res., 19, 845-869, 1999.

Farnsworth, K. L. and Milliman, J. D.: Effects of climate and anthropogenic change on small mountaneous rivers: Salinas River example, Global Planet. Change, 39, 53-64, 2003.

General Department of Land Administration: Vietnam National Atlas, Hanoi, 163 pp., 1996.

Gourou, P.: Les paysans du Delta Tonkinois, Mouton \& co, Paris, 1936.

Häglund, M. and Svensson, P.: Coastal erosion at Hai Hau beach in the Red River delta, Vietnam, Msc. thesis, supervision Larson, M. and Hansom, H., Lund University, Lund, 80 pp., 2002.

He, D. M., Ren, J., Fu, K. D., and Li, Y. G.: Sediment change under climate changes and human activities in the Yuanjiang-Red River Basin, Chin. Sci. Bull., 52, 164-171, 2007.

Hori, K., Tanabe, S., Saito, Y., Haruyama, S., Nguyen, V., and Kitamura, A.: Delta initiation and Holocene sea-level change: example from the Song Hong (Red River) delta, Vietnam, Sediment. Geol., 164, 237-249, 2004.

Kourgialas, N. N. and Karatzas, G. P.: A hydro-sedimentary modeling system for flash flood propagation and hazard estimation under different agricultural practices, Nat. Hazards Earth Syst. Sci., 14, 625-634, doi:10.5194/nhess-14-625-2014, 2014.

Krause, P., Boyle, D. P., and Bäse, F.: Comparison of different efficiency criteria for hydrological model assessment, Adv. Geosci., 5, 89-97, doi:10.5194/adgeo-5-89-2005, 2005.

Le, T. P. Q., Billen, G., Garnier, J., Théry, S., Fézard, C., and Chau, V. M.: Nutrient $(N, P)$ budgets for the Red River basin (Vietnam and China), J. Global Biogeoch. Cy., 19, 1-16, 2005.

Le, T. P. Q., Garnier, J., Billen, G., Théry, S., and Chau, V. M.: The changing flow regime and sediment load of the Red River, Viet Nam, J. Hydrol., 334, 199-214, 2007.

Lefebvre, J. P., Ouillon, S., Vu, D. V., Arfi, R., Panche, J. Y., Mari, X., Chu, V. T., and Torréton, J. P.: Seasonal variability of cohesive sediment aggregation in the Bach Dang-Cam Estuary, Haiphong (Vietnam), Geo-Mar. Lett., 32, 103-121, 2012.

Luu, T. N. M., Garnier, J., Billen, G., Orange, D., Némery, J., Le, T. P. Q., Tran, H. T., and Le, L. A.: Hydrological regime and water budget of the Red River Delta (Northern Vietnam), J. Asian Earth Sci., 37, 219-228, 2010. 
Mari, X., Torréton, J. P., Chu, V. T., Lefebvre, J. P., and Ouillon, S.: Seasonal aggregation dynamics along a salinity gradient in the Bach Dang estuary, North Vietnam, Estuar. Coast. Shelf Sci., 96, 151-158, 2012.

Mathers, S. J. and Zalasiewicz, J. A.: Holocene sedimentary architecture of the Red River delta, Vietnam, J. Coast. Res., 15, 314 $325,1999$.

Mathers, S. J., Davies, J., McDonald, A., Zalasiewicz, J. A., and Marsh, S.: The Red River delta of Vietnam, British Geological Survey Technical Report WC/96/02, British Geological Survey, Nottingham, UK, 41 pp., 1996.

Meade, R. H. and Moody, J. A.: Causes for the decline of suspended-sediment discharge in the Mississipi River system, 1940-2007, Hydrol. Process., 24, 35-49, 2010.

Milliman, J. D. and Meade, R. H.: World-wide delivery of river sediment to the oceans, J. Geol., 91, 1-21, 1983.

Milliman, J. D. and Syvitski, J. P. M.: Geomorphotectonic control of sediment discharge to the oceans: the importance of small mountain rivers, J. Geol., 100, 525-544, 1992.

Milliman, J. D., Rutkowski, C., and Meybeck, M.: River Discharge to the Sea: A Global River Index, LOICZ Core Project Office, Geesthacht, Germany, 125 pp., 1995.

Ministry of Agriculture and Rural Development: Research application on the use of MIKE21 model to assess, predict and prevent river bank erosion (north, central and south Vietnam), Technical report of the project 2006-2008 of the Ministry of Agriculture and Rural Development, Hanoi, Vietnam, 2009.

Nash, J. E. and Sutcliffe, J. V.: River flow forecasting through conceptual models, Part I - A discussion of principles, J. Hydrol., 10, 282-290, 1970.

Navarro, P., Amouroux, D., Duong, T. N., Rochelle-Newall, E., Ouillon, S., Arfi, R., Chu, V. T., Mari, X., and Torréton, J. P.: Butyltin and mercury compounds fate and tidal transport in waters of the tropical Bach Dang estuary (Haiphong, Vietnam), Mar. Poll. Bull., 64, 1789-1798, 2012.

Neary, V. S., Wright, S. A., and Bereciartua, P.: Case study: Sediment transport in proposed geomorphic channel for Napa River, J. Hydraul. Eng., 127, 901-910, 2001.

Nguyen, H. K. and Nguyen, V. T.: Geography and Hydrology in Vietnam, Vietnam Nat. Univ. publ., Hanoi, Vietnam, 194 pp., 2001

Nguyen, N. M., Marchesiello, P., Lyard, F., Ouillon, S., Cambon, G., Allain, D., and Dinh, V. U.: Tidal characteristics of the Gulf of Tonkin, Cont. Shelf Res., 91, 37-56, doi:10.1016/j.csr.2014.08.003, 2014.

Nguyen, V. P.: Streams in Vietnam, Science Publishing House, Hanoi, 209 pp., 1984.

Nguyen, V. P., Vu, V. T., and Tran, T. X.: Water resources in Vietnam, Vietnamese Institute of Meteo-hydrology, Agricultural Editor, Hanoi, Vietnam, 2003.

Ouillon, S.: Erosion and sediment transport: width and stakes, La Houille Blanche, 53, 52-58, 1998.

Ouillon, S. and Le Guennec, B.: Modelling non-cohesive suspended sediment transport in 2D vertical free surface flows, J. Hydrol. Res., 34, 219-236, 1996.

Pruszak, Z., Szmytkiewicz, M., Nguyen, M. H., and Pham, V. N.: Coastal processes in the Red River delta area, Vietnam, Coast. Eng. J., 44, 97-126, 2002.
Pruszak, Z., Pham, V. N., Szmytkiewicz, M., Nguyen, M. H., and Ostrowski, R.: Hydrology and morphology of two river mouth regions (temperate Vistula Delta and subtropical Red River Delta), Oceanologia, 47, 365-385, 2005.

Rochelle-Newall, E., Chu, V. T., Pringault, O., Amouroux, D., Arfi, R., Bettarel, Y., Bouvier, T., Bouvier, C., Got, P., Nguyen, T. M H., Mari, X., Navarro, P., Duong, T. Nghi, Cao, T. T. T., Pham, T. T., Ouillon, S., and Torréton, J. P.: Phytoplankton diversity and productivity in a highly turbid, tropical coastal system (Bach Dang Estuary, Vietnam), Mar. Poll. Bull., 62, 2317-2329, 2011.

Saito, Y., Chaimanee, N., Jarupongsakul, T., and Syvitski, J. P. M.: Shrinking megadeltas in Asia: Sea-level rise and sediment reduction impacts from case study of the Chao Phraya delta, Newsletter of the IGBP/IHDP Land Ocean Interaction in the Coastal Zone 2007/2, LOICZ, Geesthacht, Germany, 3-9, 2007.

Sassi, M. G., Hoitink, A. J. F., de Brye, B., Vermeulen, B., and Deleersnijder, E.: Tidal impact on the division of river discharge over distributary channels in the Mahakam Delta, Ocean Dynam., 61, 2211-2228, 2011.

Sassi, M. G., Hoitink, A. J. F., Vermeulen, B., and Hidayat, H.: Sediment discharge division at two tidally influenced river bifurcations, Water Resour. Res., 49, 2119-2134, 2013.

Sottolichio, A., Le Hir, P., and Castaing, P.: Modeling mechanisms for the turbidity maximum stability in the Gironde estuary, France, in: Coastal and Estuarine Fine Sediment Processes, Proc. Mar. Sci., edited by: McAnally, W. H. and Mehta, A. J., Elsevier, Amsterdam, 373-386, 2001.

Syvitski, J. P. M. and Saito, Y.: Morphodynamics of Deltas under the Influence of Humans, Global Planet. Change, 57, 261-282, 2007.

Syvitski, J. P. M., Vörösmarty, C., Kettner, A. J., and Green, P.: Impact of humans on the flux of terrestrial sediment to the global coastal ocean, Science, 308, 376-380, 2005.

Tanabe, S., Hori, K., Saito, Y., Haruyama, S., Vu, V. P., and Kitamura, A.: Song Hong (Red River) delta evolution related to millennium-scale Holocene sea-level changes, Quaternary Sci. Rev., 22, 2345-2361, 2003.

Tanabe, S., Saito, Y., Vu, Q. L., Hanebuth, T. J. J., Kitamura, A., and Ngo, Q. T.: Holocene evolution of the Song Hong (Red River) delta system, northern Vietnam, Sediment. Geol., 187, 29-61, 2005.

To, T. N.: Flood control planning for the Red River Basin, in: Proceedings of the International European-Asian Workshop: Ecosystem \& Flood 2000, 27-29 June, Hanoi, Vietnam, 2000.

Tran, D. T. and Tran, D. L.: The role of exogenous dynamics factors on sedimentologic processes in the coastal of Tonkin Gulf, Vietnam Geology, Mineralogy and Petrology, Volume 1 - Geology, Hanoi, 185-195, 1995.

Tran, D. T., Nguyen, D. C., Nguyen, H. C., and Do, D. C.: The study, predict and prevent coast erosion of Quang Ninh to Thanh Hoa, Report of KHCN-5A project, Institute of Marine Environment and Resources, Hai Phong, Vietnam, 2001.

Tran, D. T., Dinh, V. H., Nguyen, V. L., Ta, T. K. O., Tateishi, M., and Saito, Y.: The impact of human activities on Vietnamese rivers and coasts, LOICZ reports and Studies No. 26, Texel, the Netherlands, 179-184, 2002.

Tran, D. T., Saito, Y., Dinh, V. H., Nguyen, V. L., Ta, T. K. O., and Oanh, T. K.: Regimes of human and climate impacts on coastal changes in Vietnam, Reg. Environ. Change, 4, 49-62, 2004. 
Tran, D. T., Vu, D. V., Saito, Y., Do, D. C., and Tran, A. T.: An initial estimation on the effects of Hoa Binh hydropower dam on the coastal sedimentary environment in red river delta, J. Mar. Sci. Tech., 3, 1-17, 2008.

Uncles, R. J., Elliott, R. C. A., and Weston, S. A.: Observed fluxes of water, salt and suspended sediment in a partly mixed estuary, Estuar. Coast. Shelf Sci., 20, 147-167, 1985.

Uncles, R. J., Stephens, J. A., and Smith, R. E.: The dependence of estuarine turbidity on tidal intrusion length, tidal range and residence time, Cont. Shelf Res., 22, 1835-1856, 2002.

van den Bergh, G. D., Boer, W., Schaapveld, M. A. S., Do, M. D., and van Weering, T. C. E.: Recent sedimentation and sediment accumulation rates of the Ba Lat, prodelta (Red River, Viet Nam), J. Asian. Earth. Sci., 29, 545-557, 2007a.

van den Bergh, G. D., van Weering, T. C. E., Boels, J. F., Do, M. D., and Nhuan, M. N.: Acoustical facies analysis at the Ba lat delta Front (Red River Delta, North Vietnam), J. Asian Earth Sci., 29, 535-544, 2007b.

van Maren, D. S.: Morphodynamics of a cyclic prograding delta: the Red River, Vietnam, Ph.D. thesis, Netherlands Geographical Studies 324, Utrecht University, Utrecht, 167 pp., 2004.

van Maren, D. S.: Water and sediment dynamics in the Red River mouth and adjacent coastal zone, J. Asian Earth Sci., 29, 508522, 2007.

van Maren, D. S. and Hoekstra, P.: Seasonal variation of hydrodynamics and sediment dynamics in a shallow subtropical estuary: the Ba Lat River, Vietnam, Estuar. Coast. Shelf Sci., 60, 529540, 2004.

van Maren, D. S., Hoekstra, P., and Hoitink, A. J. F.: Tidal flow asymmetry in the diurnal regime: bed-load transport and morphologic changes around the Red River delta, Ocean Dynam., 54, 424-434, 2004. van Rijn, L. C.: Principles of sediment transport in rivers, estuaries and coastal seas, Aqua publications, Blokzijl, the Netherlands, 2005.

Verney, R., Lafite, R., and Brun-Cottan, J. C.: Flocculation potential of estuarine particles: the importance of environmental factors and of the spatial and seasonal variability of suspended particulate matter, Estuar. Coasts, 32, 678-693, 2009.

Vörösmarty, C. J., Meybeck, M., Fekete, B., Sharma, K., Green, P., and Syvitski, J. P. M.: Anthropogenic sediment retention: major global impact from registered river impoundments, Global Planet. Change, 39, 169-190, 2003.

Vu, D. V., Nguyen, D. C., and Tran, D. T.: The impact of Hoa Binh dam on distribution of suspended sediment in coastal areas of Red River delta, Proc. 5th Nat. Conf. Mar. Sci. Techn., 3, 465474, 2011.

Wang, H. J., Yang, Z. S., Saito, Y., Liu, J. P., Sun, X., and Wang, Y.: Stepwise decreases of the Huanghe (Yellow River) sediment load (1950-2005): impacts of climate changes and human activities, Global Planet. Change, 57, 331-354, 2007.

Wang, H. J., Yang, Z. S., Wang, Y., Saito, Y., and Liu, J. P.: Reconstruction of sediment flux from the Changjiang (Yangtze River) to the sea since the 1860s, J. Hydrol., 349, 318-332, 2008.

Whiteman, D. N., Vermeesch, K. C., Oman, L. D., and Weatherhead, E. C.: The relative importance of random error and observation frequency in detecting trends in upper tropospheric water vapor, J. Geophys. Res., 116, D21118, doi:10.1029/2011JD016610, 2011.

Yang, Z., Wang, H., Saito, Y., Milliman, J. D., Xu, K., Qiao, S., and Shi, G.: Dam impacts on the Changjiang (Yangtze River) sediment discharge to the sea: the past 55 years and after the Three Gorges Dam, Water Resour. Res., 42, W04407, doi:10.1029/2005WR003970, 2006. 